\title{
Review \\ Breast Cancer Tumor Microenvironment and Molecular Aberrations Hijack Tumoricidal Immunity
}

\author{
Huey-Jen Lin ${ }^{1, *(\mathbb{D}}$, Yingguang Liu ${ }^{2} \mathbb{D}$, Denene Lofland ${ }^{3}$ and Jiayuh Lin ${ }^{4}$ \\ 1 Department of Medical \& Molecular Sciences, University of Delaware, Willard Hall Education Building, \\ 16 West Main Street, Newark, DE 19716, USA \\ 2 Department of Molecular and Cellular Sciences, College of Osteopathic Medicine, Liberty University, \\ 306 Liberty View Lane, Lynchburg, VA 24502, USA; yliu@liberty.edu \\ 3 Department of Microbiology and Immunology, Tower Campus, Drexel University College of Medicine, \\ 50 Innovation Way, Wyomissing, PA 19610, USA; d1998@drexel.edu \\ 4 Department of Biochemistry and Molecular Biology, Molecular Medicine Graduate Program, University of \\ Maryland School of Medicine and Greenebaum Comprehensive Cancer Center, 108 N. Greene Street, \\ Baltimore, MD 21201, USA; JLin@som.umaryland.edu \\ * Correspondence: hlin@udel.edu; Tel.: +1-302-831-7576; Fax: +1-302-831-4180
}

check for updates

Citation: Lin, H.-J.; Liu, Y.; Lofland, D.; Lin, J. Breast Cancer Tumor Microenvironment and Molecular Aberrations Hijack Tumoricidal Immunity. Cancers 2022, 14, 285. https://doi.org/10.3390/ cancers14020285

Academic Editor: Alexander Arlt

Received: 24 November 2021

Accepted: 28 December 2021

Published: 7 January 2022

Publisher's Note: MDPI stays neutral with regard to jurisdictional claims in published maps and institutional affiliations.

Copyright: () 2022 by the authors. Licensee MDPI, Basel, Switzerland. This article is an open access article distributed under the terms and conditions of the Creative Commons Attribution (CC BY) license (https:// creativecommons.org/licenses/by/ $4.0 /)$.
Simple Summary: Immune therapy is designed to stimulate tumoricidal effects in a variety of solid tumors including breast carcinomas. However, the emergence of resistant clones leads to treatment failure. Understanding the molecular, cellular, and microenvironmental aberrations is crucial to uncovering underlying mechanisms and developing advanced strategies for preventing or combating these resistant malignancies. This review will summarize research findings revealing various mechanisms employed to hijack innate and adaptive immune surveillance mechanisms, develop hypoxic and tumor promoting metabolism, and foster an immune tolerance microenvironment. In addition, it will highlight potential targets for therapeutic approaches.

Abstract: Breast cancer is the most common malignancy among females in western countries, where women have an overall lifetime risk of $>10 \%$ for developing invasive breast carcinomas. It is not a single disease but is composed of distinct subtypes associated with different clinical outcomes and is highly heterogeneous in both the molecular and clinical aspects. Although tumor initiation is largely driven by acquired genetic alterations, recent data suggest microenvironment-mediated immune evasion may play an important role in neoplastic progression. Beyond surgical resection, radiation, and chemotherapy, additional therapeutic options include hormonal deactivation, targetedsignaling pathway treatment, DNA repair inhibition, and aberrant epigenetic reversion. Yet, the fatality rate of metastatic breast cancer remains unacceptably high, largely due to treatment resistance and metastases to brain, lung, or bone marrow where tumor bed penetration of therapeutic agents is limited. Recent studies indicate the development of immune-oncological therapy could potentially eradicate this devastating malignancy. Evidence suggests tumors express immunogenic neoantigens but the immunity towards these antigens is frequently muted. Established tumors exhibit immunological tolerance. This tolerance reflects a process of immune suppression elicited by the tumor, and it represents a critical obstacle towards successful antitumor immunotherapy. In general, immune evasive mechanisms adapted by breast cancer encompasses down-regulation of antigen presentations or recognition, lack of immune effector cells, obstruction of anti-tumor immune cell maturation, accumulation of immunosuppressive cells, production of inhibitory cytokines, chemokines or ligands/receptors, and up-regulation of immune checkpoint modulators. Together with altered metabolism and hypoxic conditions, they constitute a permissive tumor microenvironment. This article intends to discern representative incidents and to provide potential innovative therapeutic regimens to reinstate tumoricidal immunity.

Keywords: antigen presentation and recognition; breast cancer; immune evasion; immune-oncological targeted therapy; tumor-infiltrating lymphocytes; hypoxia; tumor microenvironment and metabolism 


\section{Introduction}

Female breast cancer (BC) is the most diagnosed malignancy, with approximately 2.3 million new cases (11.7\% of all cancer incidences) worldwide in 2020 . That number is projected to increase to over 3 million by 2040, according to the International Agency for Research on Cancer (GLOBOCAN) estimates [1].

Based on the estrogen receptor (ER), progesterone receptor (PR), human epidermal growth factor receptor 2 (HER2), as well as a BC proliferation index Ki67, our understanding of BC biology reveals 4 intrinsic molecular subtypes. They include luminal A (resembling the histological phenotype: $\left.\mathrm{ER}^{+}, \mathrm{PR}^{+}, \mathrm{HER} 2^{-}, \mathrm{Ki}^{\mathrm{L}}{ }^{\mathrm{Low}}\right)$, luminal B $\left(\mathrm{ER}^{+}, \mathrm{PR}^{+}\right.$, $\left.\mathrm{HER}^{+/-}, \mathrm{Ki}^{\mathrm{High}}\right)$, HER2-enriched $\left(\mathrm{ER}^{-}, \mathrm{PR}^{-}, \mathrm{HER}^{+}\right)$, and basal-like subtype (ER ${ }^{-}, \mathrm{PR}^{-}$, $\mathrm{HER}^{-}$) which largely resembles triple-negative BC (TNBC) and comprises approximately $15 \%$ of all BC cases [2]. The ER is found expressed in two luminal subtypes and can distinguish luminal from non-luminal malignancies [3]. Luminal A and B subtypes are characterized by their prominent activation of luminal/hormone-regulated pathways as well as proliferation/cell cycle regulators [4]. Luminal A subtype has a higher expression of luminal-related genes or proteins such as FOXA1 and lower expression of Ki67 than Luminal B [3,5]. The HER2-enriched subtype is distinguished by the high expression of HER2-related and proliferation-associated regulators such as ERBB2/HER2, insignificant expression of luminal-related genes, and negligible expression of genes related to the basal layer of the skin (e.g., keratin 5) [6]. The Basal-like subtype is characterized by high expression of Ki67 as well as keratins 5, 14, and 17, a low to undetectable expression of HER2-related genes, and unnoticeable expression of luminal-related genes [6].

The molecular subtyping helps determine the most appropriate first-line therapy. $\mathrm{ER}^{+}$ tumors are targeted with endocrine therapeutic agents such as tamoxifene, aromatase inhibitors, and abemaciclib; HER2 over-expressing tumors are generally treated with HER2blocking antibodies such as trastuzumab and pertuzumab, whereas TNBC is treated with standard cytotoxic therapies and radiotherapy [7]. However, given TNBC is frequently resistant to chemotherapy and radiotherapy, one promising treatment regimen remaining is immuno-oncology therapeutics. Considering the higher mutational burden, TNBC is known to be the most immunogenic subtype. They are frequently associated with tumorinfiltrating lymphocytes (TIL) indicative of a favorable prognosis [8].

All human nucleated cells process their intracellular proteins through the proteasome system and then present the degraded peptide fragments (the epitopes) on the major histocompatibility complex (MHC)-I. This immune complex is then scrutinized by surveillance lymphocytes. Any circulating activated T lymphocytes encountering the non-self or abnormal moieties within the peptide-MHC-I complex will either directly eliminate the target cell or produce inflammatory cytokines. After recognizing a malignant antigen, a cluster of differentiated (CD) $4^{+} \mathrm{T}$ helper (Th) cells can secrete pro-inflammatory cytokines to recruit additional immune cells and mount an immune response, whereas $\mathrm{CD}^{+} \mathrm{cy}^{-}$ totoxic T lymphocytes (CTL) can directly destroy tumor cells by secretion of cytotoxic molecules such as granzymes leading to apoptosis [9]. A successful antitumor immune response requires the following key phases: (1) capture of tumor antigens (or epitopes) by antigen-presenting cells followed by presentation them to lymphocytes; (2) activation and expansion of $\mathrm{CD}^{+}$and/or $\mathrm{CD}^{+}$lymphocytes; (3) secretion of inflammatory cytokines by $\mathrm{CD}^{+}$lymphocytes and destruction of tumor cells by $\mathrm{CD} 8^{+}$lymphocytes with involvement of dendritic cells (DCs), natural killer (NK) cells, and macrophages [10,11]. However, the tumoricidal immunity can be muted by aggressive or metastasized cancer cells leading to a detrimental phase known as "immune editing" and "immune tolerance" [12]. This review aims to not only highlight the cellular and molecular immune evasion strategies occurring at various phases, but also examine emergent therapeutic modalities that may be leveraged to overcome the immuno-oncology resistance. Due to space limitations, the authors regret that some related findings cannot be discussed in this report. 


\section{Initial Anti-Tumor Immunity Defeats Breast Neoplasm}

Breast tumors are not solely masses of excessively proliferating cells. Instead, they are intermingled with a repertoire of resident and recruited non-cancerous cells such as fibroblasts, endothelial and immune cells. These cells, along with their secreted soluble factors as well as the insoluble extracellular matrix proteins collectively constitute the tumor microenvironment (TME) [13].

The initial combined innate and adaptive immune responses are designed to eradicate tumor growth. This early phase comprises acute inflammatory reactions in response to tumor cell recognition, the secretion of proinflammatory cytokines, and the destruction of malignant cells by innate immune cells such as NK cells, DCs, and macrophages. Upon maturation, antigen-presenting cells (APCs; predominantly DCs and macrophages) migrate to nearby lymph nodes (LN) where they recognize, internalize, digest, and then present tumor antigens at the cell surface with MHC-I or MHC-II [14,15]. Next, the epitope-bound APCs activate tumor-specific $\mathrm{CD} 4^{+}$Th cells and $\mathrm{CD} 8^{+} \mathrm{CTL}$ that migrate to the tumor site and assist in killing. The activated $\mathrm{T}$ cells differentiate, proliferate, and prime for effector functions that inspect cells expressing tumor-associated antigens. After the initial immune surveillance, the tumor cells are either completely eradicated or a few immune-evading clones merge [16,17].

\section{Breast Cancer Reprograms Tumoricidal Immunity}

Leukocytes from the innate and adaptive immune systems participate not only in initial tumoral rejection but also during tumor growth progression and metastatic spread [12,18]. In the early phase of tumor evolution, host immune factors, in particular cells of the innate immune system, play a key role in the elimination of tumor cells [19]. However, in the equilibrium phase, tumor cells are maintained in a dormant state [20]. This progresses to an immune escape when the tumor variants emerge, blunting immune recognition and establishing an immunosuppressive TME [21]. Overall, these actions are consistent with the repertoire of immunoediting whereby aggressive tumors established distinct mechanisms to evade immune surveillance, establish immune tolerance, and promote their proliferation.

\subsection{Aberrant Presentation of Tumor-Associated Antigens (TAA)}

A crucial process for $\mathrm{T}$ cell recognition of tumors is MHC-binding of TAA peptides with a presentation on the surface of tumor cells or APCs. In TNBC, high levels of the MHCII antigen presentation pathway were found to be correlated with favorable progression-free survival, reduced rate of relapse, and abundant infiltration of CD8 ${ }^{+}$CTL [22]. Conversely, defects in the antigen processing and presenting machinery (APM) diminish tumor cell recognition and killing by $\mathrm{CD} 8^{+} \mathrm{CTL}$. Awareness of the functionality of APM is important when administering $\mathrm{T}$ cell-based immunotherapy protocols [23]. Furthermore, not all mutated proteins are recognized equally by $\mathrm{T}$ cells. For $\mathrm{T}$ cell recognition, neoantigens should be processed in short peptides of 9-15 amino acids. As they vary in length, only a fraction are eligible to trigger immune recognition [24].

The APM is suppressed by the expression of myelin and lymphocyte protein 2 (MAL2). Initially noted in hepatoma, MAL2 encodes a transmembrane protein associated with protein endocytosis, mainly by aiding the delivery of membrane-bound proteins and exogenous cargos from the basolateral to the apical surface [25]. Using human and mouse BC cell lines, Fang et al. demonstrated that by interacting with partner effectors, RAB7 and MHC-I molecules, MAL2 augments the endocytosis of MHC-I molecules to the late-stage endosome for degradation, downregulates $\mathrm{CD}^{+} \mathrm{T}$ cell cytotoxicity, and thus weakens immune recognition [26] (Figure 1A). High expression of MAL2 in BC decreases the stability and the level of the antigen-loaded MHC-I on the cell membrane, leading to poor antigen presentation as well as diminished cytotoxicity response from CD8 ${ }^{+}$CTL [26]. MAL2 $2^{\text {high }}$ tumors escape recognition by $\mathrm{CD} 8^{+} \mathrm{CTL}$ cells, thereby greatly increasing immune tolerance and worsening disease prognosis [26]. In another parallel study, expression of the transportassociated proteins (TAP1/TAP2), required for proper antigen loading, is concordantly 
down-regulated in high-grade BC [27]. Apart from downregulating gene expression, mutations affecting antigen presentation also provide another independent mechanism of immune escape. Mutations in $\beta 2$-microglobulin (B2M), a component of MHC-I, are shown to render immune suppressive effects and thereby become a potential target for therapy $[28,29]$.

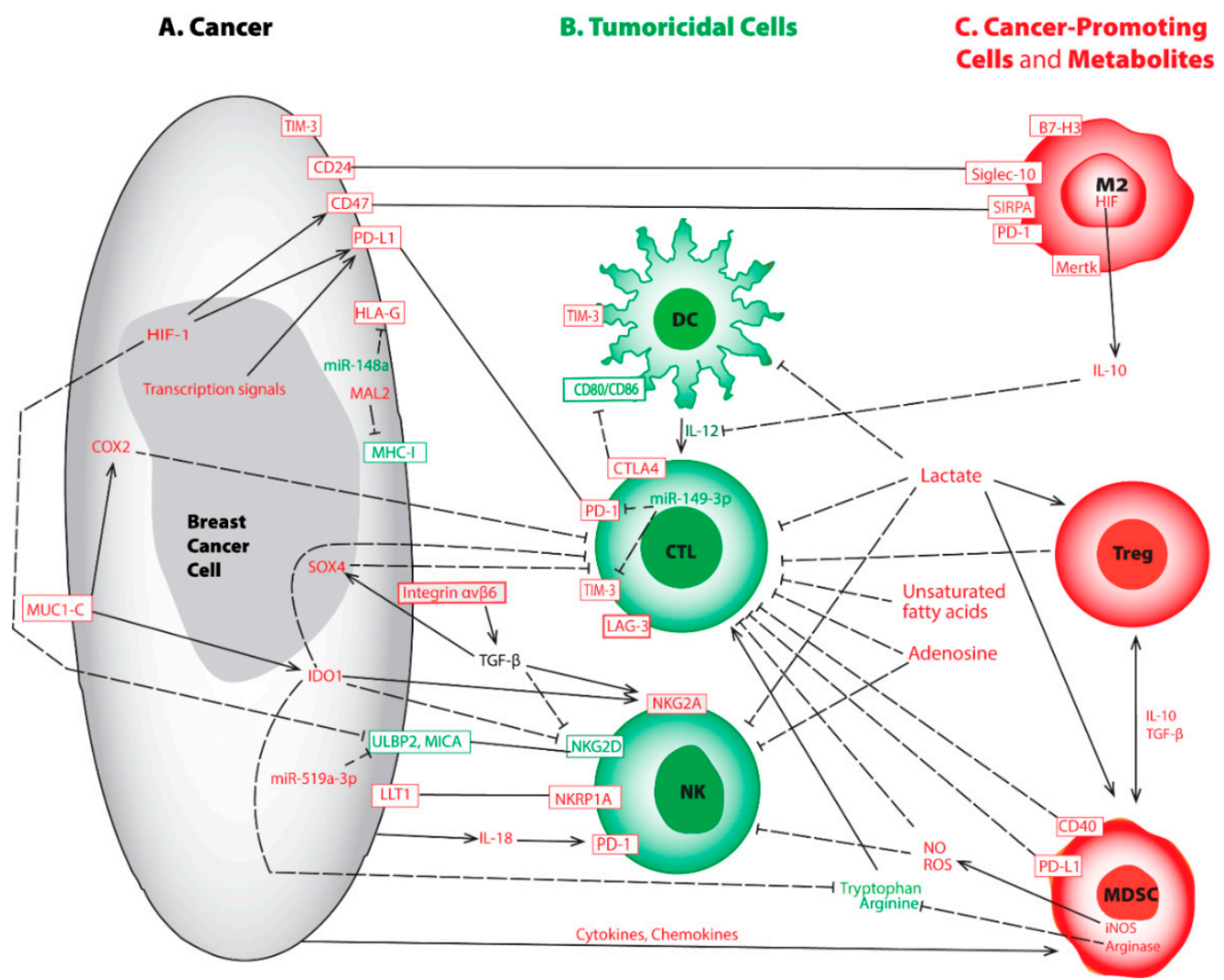

Figure 1. Representative aberrations in breast cancer cell (A), tumoricidal cells (B), cancer-promoting cells and metabolites (C) lead to immune evasion. This crosstalk map indicates the tumoricidal cells and factors (in green) and the pro-tumorigenic counterparts and factors (in red). Rectangular boxes represent cell surface molecules; plain lines indicate binding; solid arrows represent activation; and dashed lines show inhibition between modulators. Abbreviations used include cluster of differentiated (CD), CTL-associated protein 4 (CTLA-4), cyclooxygenase-2 (COX2), cytotoxic T lymphocyte (CTL), dendritic cell (DC), human leukocyte antigen G (HLA-G), hypoxia-inducible factor (HIF), indoleamine 2,3-dioxygenase (IDO), inducible nitric oxide synthase (iNOS), interleukin (IL), lymphocyte activation gene-3 (LAG-3), lectin-like transcript-1 (LLT1), M2 macrophage (M2), myelin and lymphocyte protein 2 (MAL2), major histocompatibility complex class I (MHC-I), myeloid-derived suppressor cells (MDSC), macrophage c-mer tyrosine kinase (Mertk), major histocompatibility complex (MHC), MHC-I related chain A (MICA), mucin 1 C-terminal (MUC1-C), natural killer cell $(\mathrm{NK})$, nitric oxide (NO), reactive oxygen species (ROS), regulatory T cell (Treg), programmed death receptor-1 (PD-1), programmed death-ligand 1 (PD-L1), sialic acid binding Ig like lectin-10 (Siglec-10), signal regulatory protein $\alpha$ (SIRPA), T-cell immunoglobulin and mucin domain-containing molecule 3 (TIM-3), transforming growth factor $\beta$ (TGF- $\beta$ ), and UL16 binding protein 2 (ULBP2). It is worth mentioning the sizes of various cells may be disproportional to their actual dimensions.

On the other hand, studies on high-grade BC demonstrate up-regulations of nonclassical human leukocyte antigen (HLA)-E, HLA-F, and HLA-G are important for promoting immune escape [30-32]. In BC, elevated expression of HLA-G not only renders resistance towards neoadjuvant chemotherapy (NAC) [33], but also correlates with poor prognosis [33-36]. Another independent investigation on $\mathrm{ER}^{+} \mathrm{BC}$ demonstrates that es- 
trogen signaling silences a microRNA known as miR-148a that further elevates HLA-G expression and promotes immune evasion [37] (Figure 1A; Table 1). HLA-G conveys suppressive effects on adaptive and innate immunity by interacting with immune cell inhibitory receptors such as leukocyte immunoglobulin-like receptors B1 and B2 (LILRB1 and LILRB2) or killer cell immunoglobulin-like receptor 2DL4 (KIR2DL4) [38].

\subsection{Dysfunctional CD8 $8^{+}$Tumor-Infiltrating Lymphocytes (TIL)}

NAC-induced tumor cell death results in increased TIL largely due to the release of processed antigens from dead tumor cells followed by APC uptake and presentation [39]. Among lymphocytes, CTL is associated with a favorable prognosis, and high frequencies $(>60 \%)$ of TIL are predictive for therapy response to NAC [40]. Recent studies among BC subtypes demonstrate TNBC often harbors the highest numbers of TIL and they are associated with neoantigens. However, the intra-tumoral CD8 ${ }^{+} \mathrm{CTL}$ may present at the exhausted phase due to prolonged exposure to immune-suppressive molecules in the TME $[17,41,42]$. Exhausted T cells neither produce antitumor cytokines nor execute their tumoricidal functionality $[43,44]$. Bagati et al. demonstrate, via the integrin $\alpha \mathrm{v} \beta 6-\mathrm{TGF}-\beta-$ SOX4 signaling pathway, SOX4 expression is upregulated by the integrin $\alpha \mathrm{v} \beta 6$ receptor on the surface of TNBC tumor cells thereby changing transforming growth factor (TGF)- $\beta$ from a latent precursor to an active form [45] (Figure 1A; Table 1). High expression of SOX4 not only blocks tumoricidal function normally associated with CTL but also correlates with a poor prognosis [45]. Antibody-mediated blockade of integrin $\alpha \mathrm{v} \beta 6$ attenuates SOX4 expression and restores T cell-mediated cytotoxicity [45]. Likewise, SOX4 pathway inhibition prevents the emergence of $\mathrm{MHC}-\mathrm{I}^{\text {Low }}$ tumor cells that are also refractory to $\mathrm{CD} 8^{+}$ CTL [45].

In addition, mounting evidence indicates interferon (IFN)- $\gamma$ signaling, when chronically activated in tumors, conveys an immune-suppressive TME [46,47]. Notably, the oncogenic protein mucin 1 C-terminal (MUC1-C) is aberrantly produced by TNBC, and its expression leads to both depleted and dysfunctional CTL [48,49]. Molecular studies reveal MUC1-C induces the IFN- $\gamma \rightarrow$ JAK $1 \rightarrow$ STAT1 $\rightarrow$ IRF1 signaling cascade as well as the downstream indoleamine 2,3-dioxygenase (IDO)1 and cyclooxygenase (COX)2 effectors, thereby synergistically inhibiting CD8 ${ }^{+} \mathrm{T}$ cells in TNBC [42] (Figure 1A; Table 1). Upregulation of IDO1 in TNBCs lowers the levels of tryptophan, an amino acid essential for proper T-cell proliferation and immune function in the TME [50] (Figure 1A). Similarly, elevated COX2 expression in TNBCs increases the production of prostaglandin (PG) E2 leading to T-cell dysfunction [51,52]. Targeting MUC1-C could be of clinical importance by disrupting this immunosuppression niche [42].

\subsection{Aberrant Immune Checkpoint Modulators}

Immune responses are controlled by a plethora of checkpoint regulators that act as "security brakes", to terminate immune reactions when an infection is resolved, to promote self-tolerance, and to protect against autoimmunity. Tumors exploit such immune checkpoint molecules, attempting to dampen antitumor responses, favor immune tolerance, and escape recognition and destruction [53]. Blocking the activity of one or several of these immune checkpoint molecules is shown to rescue otherwise exhausted antitumor T cells and, most importantly, to improve clinical outcomes as well as survival benefits in cancer patients [54].

\subsubsection{CTLA-4}

At the anti-tumor immune surveillance stage, $\mathrm{T}$ lymphocyte activation requires recognition of peptide-loaded MHC-I by the T-cell receptor (TCR) followed by binding between CD28 on T-lymphocytes and the counterpart ligands CD80/CD86 on APCs. However, in $\mathrm{BC}$, neoantigen recognition may result in the emergence of an inhibitory receptor known as CTL-associated protein 4 (CTLA-4), which is translocated to the cell surface. CTLA-4 is a homolog of CD28, and it harbors a strong affinity for binding CD80/CD86. This interaction 
not only hijacks the activation signal normally executed by CD28 binding but also unleashes a contrary signal that abrogates CTL function [55] (Figure 1B, Table 1). By triggering a negative feedback loop and weakening the immune surveillance effect, CTLA-4 is widely recognized as a crucial regulator of $\mathrm{T}$ cell self-tolerance and immune evasion leading to poor prognosis [56,57].

\subsubsection{PD-1 and PD-L1}

Programmed death receptor-1 (PD-1) is an inhibitory transmembrane protein expressed on T cells, B cells, macrophages, and NK cells. The interaction between PD-1 and its ligand programmed death-ligand 1 (PD-L1) on tumor cells, ignites a "stop eating me" signal that directly contributes to immune evasion via promotion of peripheral T effector (Teff) cell exhaustion and conversion to immunosuppressive T regulatory (Treg) cells, thereby hindering tumor destruction [53,58] (Figure 1A,B; Table 1). PD-L1 expression ranges from 20\% to $50 \%$ in all BC subtypes and is higher in TNBC patients as compared to non-TNBC [59-61]. High levels of PD-L1 are associated with poor overall survival (OS) [62], and elevated PD-L1 expression is involved in immune evasion and poor prognosis in TNBC [63].

Importantly, responses to checkpoint immunotherapy could be modulated by expression levels of PD-L1 on tumor cells. For instance, PD-L1 can be palmitoylated in its cytoplasmic domain, and this lipid modification sustains PD-L1 stability by preventing ubiquitination and subsequent degradation. Inhibition of palmitoylation shortens the lifespan of PD-L1 and enhances T cell-mediated tumoricidal activity [64] (Table 1). This finding is substantiated by Nouri et al. who elucidated the Hippo pathway effector, yes-associated protein, and transcriptional co-activator with PDZ-binding motif (YAP/TAZ) is critical in mediating anaplastic lymphoma kinase (ALK)-induced up-regulation of PD-L1 in multiple cancer cell lines. Knocking down YAP/TAZ impedes ALK-mediated immune evasion due to lowered PD-L1 expression [65]. Moreover, in a human BC stem cell model, elevated PD-L1 correlated with promoter CpG de-methylation and aberrant posttranslational histone modifications comprising lowered occupancy of repressive histones in the PD-L1 promoter region and overexpression of histone acetylation enzymes [66]. Further studies on the stem cell-enriched fraction of TNBC reveal that elevated PD-L1 expression can be induced by the Wingless/int1 (WNT) signaling pathway [67]. In addition, BRD4, a member of the bromodomain and extra-terminal domain, can transcriptionally up-regulate PD-L1 expression by binding to its promoter $[68,69]$.

It is worth noting that in TNBC, the signal transducer and activator of transcription (STAT)-3 and its homolog STAT1 are also involved in regulating PD-L1 expression. Mechanistic studies show that phosphorylated STAT1 binds phosphorylated STAT3 in the cytoplasm, and the complex translocate into the nucleus where this heterodimer binds the PD-L1 promoter and activates its transcription [70] (Table 1). Initially, syntenin1 was shown to induce $\mathrm{T}$ cell exhaustion in vivo. Further studies linked STAT3 with syntenin1 and demonstrated the syntenin1-driven, STAT3-dependent signaling cascade, can upregulate PD-L1 in a TNBC model [71]. Taken together, it is rationalized that targeting syntenin1, in conjunction with inhibiting STAT3, could become a potential strategy for restoring CTL activity and thereby improving the prognostic outcomes of patients with TNBC. Additional studies demonstrate the expression of PD-L1 can be elevated by Crk in TNBC [72], by neuromedin $\mathrm{U}(\mathrm{NmU})$ in $\mathrm{HER} 2^{+} \mathrm{BC}$ [73], or by exposure to radiation [74].

Given the PD-1/PD-L1 association inactivates $\mathrm{T}$ cells and attenuates tumoricidal effects, disrupting PD-1/PD-L1 binding may evolve into a promising therapeutic regimen. As of March 2019, the United States Food and Drug Administration (FDA) had approved seven immune blockade therapies for treating a variety of cancers including BC. The antibodies primarily target two major immune checkpoint pathways, PD-1, and PD-L1, as well as CTLA $[75,76]$. Accordingly, the 1st line immune checkpoint blockade therapy in combination with chemotherapy was administered for treating TNBC patients who express PD-L1 [77]. For patients who respond poorly or develop secondary resistance to immunotherapy, treatments will combine with additional epigenetic agents [78,79], or 
with chemotherapeutic agents [80]. Current investigations are underway to determine the benefits of combining immunotherapy with radiation [81-83].

\subsubsection{LAG-3}

Lymphocyte activation gene-3 (LAG-3) is a member of the immunoglobulin superfamily that was first identified in 1990 [84]. LAG-3 is expressed on activated CD4 ${ }^{+}$and CD8 ${ }^{+} \mathrm{T}$ cells and on a subset of NK cells. It is structurally similar to CD4 and binds MHC-II with a higher affinity than CD4 $[85,86]$. Although LAG-3's mechanism of action remains to be elucidated, it is certain that increased expression of LAG-3 can be triggered in chronically activated T cells $[87,88]$. LAG-3 exerts a remarkable synergy with PD-1 to transduce the inhibitory impact on activated $\mathrm{CD}^{+} \mathrm{T}$ cells (Figure 1B). This leads to immune escape [89-91] through the interaction of LAG-3's ligands available in the TME [92,93]. LAG-3 and PD-1 have been shown to be co-expressed on TIL, and blockade of both regulators had synergistic effects on restoration of the anti-tumor $\mathrm{CD}^{+} \mathrm{T}$ cell response $[90,91]$ (Figure 1B; Table 1).

\subsubsection{TIM-3}

T-cell immunoglobulin and mucin domain-containing molecule 3 (TIM-3), initially identified based upon its expression on CD4 ${ }^{+}$Th1 cells and CTL [94], is another immune checkpoint modulator that contributes to immune suppression in BC [95]. TIM-3 hampers proliferation attenuates the production of effective cytokines and augments apoptosis of effector T cells, through interaction with its ligands galectin-9, high mobility group protein B1 (HMGB1), carcinoembryonic antigen-related cell adhesion molecule 1 (CEACAM-1), and phosphatidylserine [95-97]. TIM-3 is expressed on a variety of immune cells including T lymphocytes, DCs, and BC cells [98] (Figure 1A,B).

Upon studying DCs, blockade of TIM-3 by introducing anti- $(\alpha)$ TIM-3 antibodies improves response to paclitaxel chemotherapy in murine models of luminal B and TNBC diseases [99]. Furthermore, through prolonged exposure to IL-12, combined efficacy not only boosts the effector function of intertumoral CTL but also elevates granzyme B expression with minimal cytotoxicity [99] (Table 1). Another independent study shows TIM-3 inhibits the production of the chemokine CXCL9/10 by DCs thereby limiting antitumor immunity in mammary carcinomas [100]. TIM-3 blockade, similarly, enhances response to paclitaxel, augments uptake of extracellular DNA by DCs through an endocytic process, and renders re-activation of the cytoplasmic DNA-binding by HMGB1 as well as sensing by the cyclic GMP-AMP synthase (cGAS) and stimulator of IFN genes (STING) pathway in DCs [100]. Together, upon TIM-3 blockade, elevated chemokines released from DCs can strengthen $\mathrm{T}$ cell effector function and response to chemotherapeutic treatment $[99,100]$. The immune surveillance function of DCs within tumors is emerging as a critical determinant of an effective T cell response [101], and TIM-3 inhibition depicts not only chemotherapeutic susceptibility but also promising efficacy in cancer immunotherapy.

On the other hand, TIM-3 overexpression in BC cells promotes cell proliferation, migration, invasion, and enhances chemoresistance to paclitaxel through the overly activated NF- $\kappa$ B/STAT3 pathway [102]. STAT3 signaling displays a plethora of roles in immune cells and promotes the immunosuppressive function in the TME [103]. TIM-3 overexpression in BC cells activates the STAT3 signal pathway that promotes crosstalk between cancer and immune cells [104]. TIM-3 also destroys tight junctions, which further accelerates cancer progression [102]. Conversely, downregulation of TIM-3 in BC cells inhibits their proliferation, migration, invasion, and promotes apoptosis [105].

One of the microRNAs, miR-149-3p, has been reported to bind $3^{\prime}$ UTRs of mRNAs encoding PD-1, TIM-3, and other immune checkpoints [106]. Treatment of CTL with miR-149-3p mimic rescues T-cell exhaustion, downregulates PD-1 and TIM-3, and thereby promotes the killing of 4T1 mouse breast tumor cells [106] (Table 1). Moreover, TIM-3 has recently emerged as a promising target for cancer immunotherapy, because it is a non-redundant regulator that differs from other better-characterized checkpoints. Several prospective studies and clinical trials have been launched in solid tumors [107]. $\alpha$ TIM-3 
partially reverses this exhausted phenotype, results in improved expression of IFN- $\gamma$, and suppresses tumor growth in multiple preclinical models [108]. $\alpha$ TIM-3 antibodies have revealed successful efficacious treatment synergy when combined with $\alpha$ PD-1 [109] or when it is used subsequently in $\alpha$ PD-1 refractory cancers [110].

Mounting evidence demonstrates blocking one immune checkpoint can result in the upregulation of alternative modulators which potentially synergizes T cell exhaustion [111] and gives rise to compensatory mechanisms for immune evasion [111,112]. As a result of these studies, there are several antibodies against TIM-3 (e.g., TSR-022/Cobolimab, MBG453, LY3321367, BMS986258) being evaluated in clinical trials, mostly in combination with additional agents abrogating PD-1 and PD-L1 pathways [100]. Hence, future innovative BC treatment regimens may comprise TIM-3 co-blockage with additional checkpoint modulators, through the delivery of a blockade antibody cocktail or with miR-149-3p, in conjunction with non-immune-based protocols such as chemotherapy.

\subsection{Dichotomic Roles of Natural Killer (NK) Cells}

During normal immune surveillance, NK cells and CTL express NKG2D receptors to detect malignant or damaged cells via recognition of a cellular stress response-induced ligand surge [113]. The NKG2D/NKG2DL axis renders cytotoxic activity and induces anti-tumor cytokines [114] (Figure 1B).

However, NK cell function is also modulated by various activating and inhibitory receptors interacting with their respective ligands on target cells. For instance, Lectin-like Transcript-1 (LLT1, CLEC2D, OCIL) is a ligand on BC that interacts with NK cell receptor NKRP1A (CD161) leading to inhibition of NK cell-mediated cytolysis [115] (Figure 1A,B). Blocking LLT1 with antibodies or knocking down of the gene LLT1 impedes this interaction and enhances the destruction of TNBCs by NK cells [116] (Table 1). Similarly, NK cells from invasive cancers express lowered NKG2D, and yet, elevated inhibitory receptors (one of which is NKG2A) due to a mechanism modulated by immunosuppressive cytokines (e.g., TGF- $\beta$ and IDO1) in the TME [117] (Figure 1A,B). Another independent mechanism conveying immune escape is weakened antibody-dependent cell-mediated cytotoxicity, thus constraining antitumor effects [118]. Furthermore, interleukin (IL)-18, present in the TME, can upregulate PD-1 expression on NK cells resulting in a profound immunesuppressive outcome [119] (Figure 1A,B).

Moreover, microRNAs produced by some tumor cells combat immune surveillance by influencing neighboring metastatic sites, adjacent immune cells, or the TME. MiR-519a-3p reduces tumor destruction by $\mathrm{NK}$ cells in two ways. It downregulates the ligands for NKG2D, UL16 binding protein 2 (ULBP2), and MHC-I related chain A (MICA), on the surface of cancer cells leading to obstructed recognition by NK cells [120] (Figure 1A,B). Furthermore, miR-519a-3p weakens the expression of target genes such as tumor necrosis factor-related apoptosis-inducing ligand-receptor 2 (TRAIL-R2), caspase-7, caspase-8, and granzyme B which are crucial for the apoptosis cascade [120]. Taken together, miR-519a-3p protects BC cells from NK cell-mediated destruction and increases resistance to apoptotic death, and thus synergistically contributing to immune evasion [120] (Table 1).

\subsection{Elevated Regulatory T Cells (Treg) Suppress Immune Response and Promote Tumor Growth}

As opposed to the $\mathrm{CD} 8^{+} \mathrm{CTL}$, the prognostic role played by $\mathrm{CD}^{+} \mathrm{T}$ lymphocytes is of lesser weight because its subpopulation is quite heterogeneous. It comprises at least four distinct lineages, namely Th1, Th2, Th17, and Tregs, each with unique and at times opposing functions [121]. Tregs, with FOXP3 as the specific and reliable marker, normally act to suppress T-cell responses following the resolution of infections and are crucial for preventing autoimmune diseases. However, tumors can divert this modulatory mechanism and elevate the numbers of Tregs [122].

Apart from playing important roles in maintaining homeostasis, Tregs facilitate BC proliferation, immune evasion, and metastasis, through the production of protumorigenic cytokines and expression of immunomodulatory receptors [123,124] (Figure 1C). 
As such, the abundance of Tregs in breast tumor biopsies is linked to poor relapse-free survival, OS, and prognosis [125,126]. Moreover, RUNX3, a CD8 ${ }^{+}$lineage-specific transcription factor, was shown to bind FOXP3-promoter, enhance its transcription, and increase Treg population in the TME leading to worsened prognosis [127-129]. The association of intratumoral Tregs in advanced BC is explained by the upregulation of Treg-attracting chemokines in tumor cells $[125,130,131]$, with concomitant induction of inflammatory mechanisms promoting tumor metastasis [132]. Acting as predictive biomarkers, the balance between intratumoral CTL and Treg populations greatly influences the outcome of clinical responses after neoadjuvant chemotherapies $[133,134]$ as well as a pathological complete response [135].

\subsection{Polarizing Anti-Tumor Macrophage (M1) to Tumor-Promoting Macrophages (M2)}

Monocytes are often recruited to the TME in response to stimuli with subsequent differentiation to macrophages via crosstalk with cytokines and chemokines [136]. With this unique plasticity and influence by external cues, macrophages are the key elements orchestrating various aspects of TME immunity. They participate in innate as well as adaptive immunity, during both the anti-tumor phase and pro-tumoral immune evasion. Macrophages within early neoplastic tissues are frequently tumoricidal. Yet, prolonged exposure to the TME bestows them with protumorigenic properties. This suggests that macrophage plasticity may be therapeutically exploited to restore initial tumoricidal properties [137].

Under the influence of microenvironmental signals, macrophages can be polarized into two immunologically distinct subsets, M1 (classically activated, anti-tumoral) and M2 (alternatively activated, pro-tumoral) [138]. M2 produces various tumor-promoting factors with the most prominent being vascular endothelial growth factor (VEGF), IL-6, IL-10, and TGF- $\beta[139,140]$ (Figure 1C). Notably, Ham et al. report that exosomes (the membranebound extracellular vesicles) released by BC cells can skew macrophage polarization toward the M2 phenotype partially via gp130/STAT3 signaling [141]. While M1 macrophages are largely involved in the milieu of normal immune reactions, prolonged exposure to a poorly vascularized TME stimulates macrophages to upregulate hypoxia-inducible factors (HIF)- $1 \alpha$ and HIF- $2 \alpha$. This provides metabolic adaptation to an oxygen-poor environment and polarizes macrophages towards M2 to execute immunosuppressive functions [142].

M2 are predominantly marked by CD163 and account for the majority of tumorassociated macrophages (TAM). They also play pleiotropic roles in establishing a TME favorable for tumor growth, metastatic spreading, invasion, migration, angiogenesis, and secretion of soluble mediator cytokines and chemokines [143,144]. Studies in mouse models of BC show TAMs impair CD8 ${ }^{+}$CTL activation and proliferation through an IL-10dependant manner. Briefly, IL-10 inhibits the production of IL-12 by dendritic cells that subsequently suppresses tumoricidal actions exerted by CTL [145] (Figure 1B,C).

Immune checkpoint regulators in the TME provide "stop eating me" signals to hinder phagocytosis. TAMs not only express PD-1 $[146,147]$ to evade killing by CTL, but also produce signal regulatory protein $\alpha$ (SIRPA) to block phagocytosis after binding with CD47 receptors on the surface of tumor cells $[148,149]$ (Figure 1A,C). On the other hand, mounting evidence indicates that TAMs express high levels of Sialic Acid Binding Ig Like Lectin (Siglec)-10 while tumors overexpress CD24 (Figure 1A,C). Genetic ablations of Siglec-10 or CD24 and antibody blockade of the CD24-Siglec-10 complex greatly enhance phagocytosis [150]. These data highlight the role of CD24 as an anti-phagocytic signal and demonstrate its therapeutic potential [150]. CD24-deficient cells were also significantly more sensitive to CD47 blockade than normal control cells, suggesting the cooperativity of combinatorial blockade of CD24 and CD47 [150]. Dual treatment with CD24 and CD47 blocking antibodies demonstrates a vigorous induction of phagocytosis [150] (Figure 1A,C; Table 1). In a parallel context, macrophages present in mammary tumors undergo a substantial reduction of MHC-II expression mediated by tumor-expressed macrophage 
migration inhibitory factor (MIF). This subsequently inhibits antigen presentation and hinders adaptive immune induction [151,152].

B7-H3 is another nonredundant immune checkpoint modulator expressed in tumor cells, tumor vascular endothelial cells, macrophages, and other APCs. It has been widely studied in the context of tumor progression and immune evasion [153]. B7-H3 expression is elevated in TAMs of TNBC patients and strongly correlates with poor prognosis. B7-H3 ${ }^{\text {high }}$ TAMs exhibit great pro-metastatic and immunosuppressive activity by remodeling extracellular matrix (ECM) and expanding tumor angiogenesis, thereby enhancing tumor cell dissemination, and reducing T-cell infiltration into the TME [154] (Figure 1C). B7-H3 inhibition by antibodies exerts a detrimental effect on TAM, as well as the TME, and thus, restricts tumor growth [155] (Table 1).

Likewise, another independent M2 receptor known as macrophage c-mer tyrosine kinase (Mertk), was shown to correlate with a poor prognosis due to its capacity to sustain an immunosuppressive environment [156] (Figure 1C; Table 1). Blockade of Mertk function on macrophages decreased efferocytosis and altered the cytokine milieu. Similarly, Mertk-knockout mice or administering anti-Mertk neutralizing antibodies altered the cellular immune profile, resulting in an inflamed tumor environment with enhanced T-cell infiltration into tumors and improved cytotoxicity [156].

\subsection{Myeloid-Derived Suppressor Cells (MDSC)}

At the conclusion of normal hematopoiesis, immature myeloid progenitor cells (IMCs) usually differentiate into mature granulocytes, monocytes, or DCs which play essential roles in host defense against invading pathogens. However, in pathologic circumstances such as cancers, IMCs fail to proceed to a typical differentiation but rather acquire features of immature and dysfunctional myeloid populations known as myeloid-derived suppressive cells (MDSC) [157]. Circulating MDSC in peripheral blood of BC patients is elevated in all stages of the disease and positively correlated with high cancer grades as well as an extensive metastatic burden [158].

Reprogrammed by breast tumors, MDSC not only creates a tolerogenic environment by inducing Treg and blocking CTL function as well as proliferation, but also directly drives tumor growth by promoting angiogenesis, epithelial-to-mesenchymal transition, stemness, and metastasis [157,159-161]. MDSC can alternatively differentiate into TAM that are immune-suppressive and sustain cancer stem cell characteristics [162]. Yet, their primary action is through deterioration of innate and adaptive immune tumoricidal responses [161,163]. MDSC release arginase that depletes L-arginine from the TME and cripple $\mathrm{T}$ cell function, as well as produce reactive oxygen species (ROS) and nitric oxide (NO) that impede immune cell signal transduction [164] (Figure 1C).

Via a paracrine feedback loop, T lymphocytes secrete IFN- $\gamma$ that plays a crucial role in augmenting MDSC in a breast tumor-bearing mice model [165]. These MDSC express CD40 and PD-L1 to attenuate the antitumor response of T cells [166-168] (Figure 1C). Notably, inflammatory cytokines such as PGE2, IL-6, and IL-1 $\beta$, commonly produced from chronic inflammatory responses or released from tumors, can increase MDSC [169-174]. These findings depict an important linkage between chronic inflammation and tumor progression.

Indoleamine 2,3-dioxygenase (IDO), the enzyme catalyzing oxidative cleavage of tryptophan to $N$-formylkynurenine, can lower tryptophan in the TME and exacerbate antigen-specific tolerance in T cells [175]. IDO is often released from tumors and is responsible for recruiting MDSC and fostering an immune-suppressive TME [175] (Figure 1A,C). Furthermore, TNBC secretes a variety of cytokines and chemokines, such as granulocyte colony-stimulating factor (G-CSF) and granulocyte-macrophage colony-stimulating factor (GM-CSF), to promote MDSC development $[159,176,177]$. Their underlying molecular mechanism was recently revealed by Li et al. [177]. Their study reports excessive aerobic glycolysis in TNBC orchestrates a molecular network leading to elevated expression of liver-enriched activator protein (LAP) that efficiently increases G-CSF and GM-CSF expression [177]. In TNBC, the effective recruitment of MDSC to the primary tumor and metastatic 
sites also requires another set of chemokines, CXCL2, and CCL22, that are activated by a transcription factor $\Delta \mathrm{Np} 63$ produced by tumors [178] (Figure 1A,C). Together, these findings identify innovative and non-redundant options via eradicating MDSC for treating such a devastating malignancy.

\section{Tumor Stroma, Mediators, Chemical Components, and Physical Factors Constitute the Tumor Microenvironment (TME)}

The theory of cancer cell plasticity hypothesizes that the ability of tumors to adapt their phenotypes or functions is important for controlling disease progression, metastatic spread, immune evasion, and treatment outcomes [179]. A plethora of regulators produced by cancer cells, immune cells, and cancer-associated stroma (CAS) not only constitute the TME, but are also critical for coordinating cancer plasticity and immune escape. For example, elevated circulating IL-9 levels in BC patients were shown to enhance atypical anti-tumor immunity [180]. Contrarily, IL-18 present in the TME can upregulate PD-1 expression on NK cells, resulting in an immune-suppressive phenotype [119].

Mounting evidence indicates tumor stroma participates in nearly all stages of carcinogenesis and exclusion or dysfunction of $\mathrm{CD}^{+} \mathrm{T}$ cells and is correlated with an abundance of immune-suppressive cells, including M2, MDSC, Tregs, and CAS [181]. Furthermore, syndecan-2, secreted by CAS and released into the TME, can induce TGF- $\beta$ signaling and upregulate CXCR4 and PD-L1 expression leading to deteriorated immune surveillance [182]. Conversely, inhibition of syndecan- 2 not only attenuates TGF- $\beta$ signaling, impedes PD-L1 expression, tumor growth, and metastasis, but also elevates immunotherapy susceptibility in breast tumors [182] (Table 1).

\subsection{Dysregulated Cytokines and Chemokines}

Produced by immune cells, CAS, and tumor cells, soluble mediators comprise a variety of growth factors, cytokines, and chemokines. Several of them are reported to closely participate in tumor progression, invasion, and immune escape. These include tumor necrosis factor alpha (TNF- $\alpha$ ), transforming growth factor beta (TGF- $\beta$ ), insulin-like growth factor 2 (IGF-2), vascular endothelial growth factor (VEGF); cytokines IL-1, IL-4, IL-6, IL-8, IL-10; and chemokine (C-X-C motif) ligand 1 [183].

$\mathrm{BC}$ tumors engage a paracrine loop and crosstalk with the TME to suppress T-cell infiltration and function. By releasing an extracellular regulator, galectin-3, tumor cells are capable of blocking interferon gamma (IFN- $\gamma$ ) in the TME followed by impeding chemokines CXCL9, CXCL10, and CXCL11 leading to obstructed T-cell recruitment into the tumor bed [184] (Table 1). In addition to inactivating IFN- $\gamma$, galectin-3 conveys broad effects by binding to glycans that are associated with various glycoproteins in the extracellular matrix and forming lattices with oligomerization, as well as resulting in their inactivation. Given human cytokines are mostly glycosylated, galectin-3 secretion could depict a general strategy for tumor immune evasion and provide a potential therapeutic target. In addition, the function of CTL in the tumor bed can be inactivated by inhibitory mediators, such as IL10, IDO1, reactive oxygen species (ROS), and nitric oxide (NO) released from immunesuppressive Treg and MDSC [185] (Figure 1C), indicating synergistic networking among so-called hijacked immune cells conveys tumor-promoting outcomes.

\subsection{Altered Signaling Pathways}

Tumor cells circumvent TIL and antigen presentation by utilizing the mitogen-activated protein kinase (MAPK) pathway. In TNBC, a lack of TIL is correlated with activated RAS/MAPK pathway [186] (Table 1). Overly activated Ras/MAPK pathway is associated with low TIL densities, impaired IFN- $\gamma$ signaling, and down-regulated MHC-I and MHC-II expression, leading to reduced immune recognition. The finding was substantiated in a TNBC mouse model in which MEK inhibition upregulated the expression of cell surface MHC expression and PD-L1, both in vivo and in vitro [186]. Therefore, the dual MEK plus PD-L1/PD-1 inhibition synergized antitumor immune responses [186]. In another inde- 
pendent study, Franklin et al. found MEK inhibition not only affects the tumor-immune microenvironment by altering the expression of interferon-inducible MHC-I and PD-L1 expression, but also enhances immunogenicity and improves susceptibility to immune checkpoint blockade therapy [187].

The activation of IL-1 receptor family members (ILRs) along with Toll-like receptors (TLRs) constitute a critical sensing mechanism controlling tumor death or survival [188]. ILRs and TLRs activation promotes various signal transduction cascades with pro-inflammatory outcomes, including activation of NF- $\mathrm{kB}$, and secretion of TNF- $\alpha$. They are, in turn, necessary for $\mathrm{NK}$ and $\mathrm{DC}$ activation, along with $\mathrm{CD} 8^{+} \mathrm{CTL}$ priming, to combat tumor antigens $[189,190]$. Therefore, activation of ILRs and TLRs plays an important role in inflammation, initiation, and amplification of innate and adaptive immunity [191]. Conversely, interleukin-1 receptor 8 (IL-1R8) suppresses signaling from IL-1R1, IL-18R, and TLRs [192,193]. IL-1R8 is up-regulated during breast epithelial cell transformation and in primary BC. High IL-1R8 expression correlates with impaired innate immune sensing and T-cell exclusion, based on the immune-gene signature analysis of clinical specimens [188]. IL-1R8 expression in transformed breast epithelial cells lowered IL-1-dependent NF- $\mathrm{B}$ activation as well as production of pro-inflammatory cytokines, impeded NK cell activation, and favored M2 macrophage polarization [188].

\subsection{Aberrant Metabolism}

Metabolic interactions between tumors and immune cells lead to dysfunctional immunity as exemplified by exhausted T lymphocytes [194]. Mounting evidence reveals a variety of tumors actively reprogram metabolic pathways to escape tumoricidal immunity. Reports indicate glycolysis regulates T cell activation and effector function in TNBC [177]. Dysregulated metabolism in tumors is commonly linked to increased aerobic glycolysis. This important and unique phenomenon, termed the Warburg Effect, demonstrates the continued fermentation of glucose in the presence of adequate oxygen [195]. Accelerated glycolytic metabolism by the tumor shapes the TME and represents one of the profound mechanisms promoting immunosuppressive infiltrates [196,197]. Glycolytic tumors express transporters including the monocarboxylate transporter (MCT) 4 that exports lactate to the extracellular constituents. This results in an acidified TME leading to strengthened tumor invasion, metastasis, and immune evasion [198]. Accumulation of lactic acid not only blunts anticancer immunity but also increases Tregs and impairs CTL [199,200] (Figure 1C). Studies show lactate enhances the production of MDSC from the bone marrow of mice while suppressing NK cells leading to weakened cytotoxicity [201] (Figure 1C). Furthermore, lactate skews macrophages toward the tumor-promoting M2 phenotype and upregulates PD-L1 to enhance immune escape [202-204]. Therefore, an increased lactate concentration in the TME serves as not only a potential therapeutic target, but also a poor prognosticator [198].

Recent studies indicated GPR81, a G protein-coupled receptor for lactate, is upregulated in BC, and it plays both paracrine and autocrine roles to promote tumor growth through tumor-derived lactate. In the paracrine mode, the tumor-secreted lactate activates GPR81 in dendritic cells and diminishes the presentation of tumor-specific antigens to neighboring immune cells [205]. This paracrine system is complementary to the recently discovered autocrine mechanism in which lactate enhances PD-L1 expression via activation of GPR81 in tumors, thus providing an effective means for evading the immune system [206] (Table 1). As such, blocking GPR81 signaling could provide a significant enhancement of immunotherapy.

On the other hand, secretion of unsaturated fatty acids bestows another immune evasion mechanism, by inhibiting anti-tumor effects exerted by CTL [207] (Figure 1C), thereby linking obesity with a high risk of acquiring BC. Furthermore, fatty acid $\beta$-oxidation is one of the characteristics associated with M2, as well as Tregs [208,209]. Together, these phenomena emphasize the impact of altered metabolism on cancer progression. 
During the course of infection or tumor progression, high levels of ATP are released into the extracellular space within the inflamed tissues or tumors [210]. Extracellular ATP acts as a proinflammatory alarm for the immune system by enhancing chemoattraction of DCs and activating monocytes and macrophages. Yet, degradation of ATP into adenosine (Ado) by murine Tregs is correlated to immunosuppression [211,212], particularly within the TME [213]. Ado is produced from sequential cleavages by enzymes CD39 and CD73 expressed by both cancer and immune cells in the TME [211,212,214]. Extracellular ATP is first converted to AMP by CD39, and the subsequent dephosphorylation of AMP to adenosine is catalyzed by CD73 [211]. Ado can favor tumor progression by impeding the cytotoxic activity of CD8 ${ }^{+}$CTL and NK cells through binding of receptors A2a or A2b [215-217] (Figure 1C; Table 1). Two crucial properties are associated with $\mathrm{CD}^{+}{ }^{+} \mathrm{T}$ cells. First, they are largely devoid of immune checkpoints, indicating the Ado/AdoR axis is likely a revolutionized variant selected after immune checkpoint therapy. Second, these cells promote "metabolism"-driven immune tolerance. Hence, combinatorial therapy targeting non-redundant pathways Ado/AdoR axis enhances treatment efficacy [212,214,216].

\subsection{Hypoxia Conveys Tumor Cell Plasticity}

Due to structurally reorganized blood vessels and tumor growth exceeding the rate of vascularization, tumor hypoxia is common. These tumors have a median oxygen concentration of $1.4 \%$, as opposed to approximately $9.3 \%$ for normal breast tissue [218]. Hypoxia plays a significant role in tumor cell plasticity. BC can be highly hypoxic, and the tumor cells located in a hypoxic TME are primarily aggressive and resistant to immunotherapy [219]. Hypoxia upregulates hypoxia-inducible factor $1 \alpha(\mathrm{HIF} 1 \alpha)$-dependent ADAM10 that further induces MICA to be shed from the surface leading to poor antigen detection [220].

Moreover, HIF-1 stimulates CD47, a cell-surface protein that binds SIRPA on the surface of macrophages, thereby blocking phagocytosis [221] (Figure 1A,C). Interestingly, chemotherapeutic treatments cause coordinated transcriptional induction of CD47, as well as CD73 and PDL1, in TNBC cells [222]. Importantly, such an aberration can be blocked by an independent regimen of HIF-1 inhibition. This study suggests the inclusion of HIF inhibitor may prevent the unwanted countertherapeutic effects [222] (Table 1). As CD73 expression is induced by hypoxia in a HIF-dependent manner, HIF inhibition might also improve the clinical responses to treatments by blocking the Ado signaling pathway [223]. In another reversal study, under hypoxic conditions, elevated HIF-1 directly upregulates the transcription of CD47 in BC cells leading to the enhanced escape of phagocytosis by macrophages and the maintenance of CSCs [221]. HIFs have been similarly reported to promote polarizing MDSC towards M2 [224], induce Treg [225], and increase the expression of PD-L1 [167].

\subsection{Extracellular Microvesicles (EVs) Modulate Immune Evasion}

The communication between distant cells requires transferring of microRNAs, proteins, and lipids encapsulated in cargo-like structures known as extracellular microvesicles (EVs) [226]. EVs affect a variety of cellular and molecular pathways not only in cancers but also in other physiological and pathological conditions [227].

In cancers, EVs possess immunosuppressive properties and participate in the transfer of these traits to recipient cells. EVs are classified according to their size and the mechanisms by which they are made. Exosomes are 30-120 nm in size and are generated from the internal compartment of a cell, whereas microparticles (MPs) are 0.1-1.0 $\mu \mathrm{m}$ and produced from outer cytoplasmic membrane blebbing or shedding [228]. While exosomes play pleiotropic roles regulating the complex intracellular pathway involved in all steps of BC progression, tumor-derived microparticles (TMPs) are associated with therapy resistance [228]. For example, under hypoxic conditions, exosomes derived from two BC cell lines exert a potent immunosuppression activity by inhibiting T-cell proliferation through the TGF- $\beta$-signaling cascade [229]. Another independent study reveals BC cells' exosomal miR-503 promotes polarization towards M2 and suppresses T-cell proliferation [230]. EVs 
have been shown to orchestrate a broad spectrum of immunosuppressive events at different immune response stages, including modulation of $\mathrm{T}$ cell proliferation and function, regulation of NK cell function, maturation of DCs, the polarization of M2 macrophages, hindrance of antibody-mediated cytotoxicity, and induction of MDSC and Tregs [231,232].

EVs released from treatment-resistant variants of HER2 ${ }^{+} \mathrm{BC}$ contained high levels of the immunosuppressive cytokine TGF- $\beta 1$ and increased PD-L1, and were resistant to HER2 antibody trastuzumab-mediated cytotoxicity [73]. TGF- $\beta 1$ in EVs is shown to contribute to immunosuppressive effects [229], and EVs from drug-resistant cells are able to disseminate the trait and raise the levels of TGF- $\beta 1$ in drug-sensitive recipient cells [73]. In a parallel neoadjuvant clinical trial, the TGF- $\beta 1$ level was significantly higher in EVs isolated from the serum of HER2 ${ }^{+}$patients who poorly respond to HER2-targeted drug treatment, as compared to those yielded from the serum of patients with partial or complete susceptibility [73]. These findings illustrate the pleiotropic function of EVs in transmitting immune-suppressive cues. As such, analyzing the constituents in EVs may uncover biomarkers important for predicting treatment efficacy [233].

\subsection{Radiation Influences Tumoricidal Immunity}

Ionizing radiation is generally used to treat a localized target, and radiotherapy plays a pivotal role in curing cancer. Ionizing radiation applied locally to the tumor site typically causes DNA damage and subsequent cell death [234]. Radiation activates several systemic biological responses, including adaptive and innate immunity that further impact tumor progression [235]. Given radiation-deceased tumor cells can stimulate dendritic and cytotoxic T-cell activity directed against viable tumor cells [236], tumors or metastatic sites distal to the initial irradiated field should, hypothetically, respond favorably to the radiation. This phenomenon is termed the "abscopal effect" [233]. However, such antitumor effects are rarely reported clinically. Instead, radiation causes not only anti-tumorigenic but also pro-tumorigenic activities, which may explain the limited response to radiotherapy.

Radiotherapy is demonstrated to induce the expression of CXCL16, one of the proinflammatory cytokines that enhances the chemotaxis of CTL cells into the tumor bed and increases their ability to execute anti-tumor cytotoxicity [237]. Contrarily, preclinical studies report macrophages exposed to radiation promote metastasis [238]. Accordingly, the elimination of macrophages from irradiated hosts attenuates tumor growth and metastasis [238]. Furthermore, Ahn et al. reported that myeloid cells in tumor-bearing mice migrate to the irradiated tumor site and accelerate tumor angiogenesis and regrowth [239]. Since pro-tumorigenic immune responses contribute to tumor re-growth, it is rationalized that blocking these unwanted reactions can improve radiotherapy outcomes. Moreover, the expression of PD-L1 on tumor cells is largely altered in response to radiation, thereby potentially contributing to the immunomodulation activity of radiotherapy $[240,241]$. In a TNBC model, suppressing Treg via phosphoinositide 3-kinase $\delta$ (PI3K $\delta$ ) inhibition plus immune checkpoint therapy abrogating PD-1, improves the efficacy of radiation therapy [242].

\section{Conclusions}

It was widely recognized that the complex interplay between immunity and tumor determines whether tumor cells will survive or be destroyed. The battle between immune surveillance and tumor-promoting activities relies on the extent to which the antitumor immune response is exerted. The main hurdle for generating a broad and robust antitumor immune response is overcoming immune escape. Tumor and immunologic constituents shed light on potential mechanisms of immune evasion in $\mathrm{BC}$ and the unique aspects of the TME. These include elements associated with antigen processing and presentation as well as immunosuppressive constituents, which may be targeted therapeutically. Examples of such immune-therapeutic strategies include efforts to (1) enhance CTL and NK cells; (2) boost immunostimulatory DCs; (3) improve antigen presentation; (4) block inhibitory cytokines or chemokines; (5) inhibit immune checkpoint blockades such as PD-1, PD-L1, CTLA-4, LAG-3, and TIM-3; (6) reprogram tumor-promoting M2 towards antitumor M1 
macrophages; (7) differentiate Treg and MDSC to restore their tumoricidal functions; and (8) correct aberrant metabolisms (partly exemplified in Table 1). The goal of these approaches is to shift the balance and increase BC's susceptibility to immunotherapy and other treatments. After surgical resection, rather than administering monotherapy targeting a single aberration, multiple immuno-therapy agents in conjunction with chemoor radiation-mediated, hormone therapy-mediated, kinase-targeted, DNA repair-disrupted, aberrant epigenome-involved, and cytokine-intricated treatments, may ignite promising treatment regiments to eradicate this most common female cancer.

Table 1. Representative therapeutic targets combat immune evasion of breast cancer.

\begin{tabular}{|c|c|c|c|}
\hline Therapeutic Agent & Target & Rationale & Reference(s) \\
\hline miR-148a mimic & HLA-G & Non-classical HLA promotes immune escape & [37] \\
\hline av $\beta 6$ antibody & $\alpha \mathrm{v} \beta 6$-TGF $\beta$-SOX4 pathway & SOX4 inhibits CTL & [45] \\
\hline $\begin{array}{l}\text { shRNA silences } \\
\text { MUC1-C }\end{array}$ & MUC1-C & MUC1-C enhances IFN- $\gamma$ signaling that inhibits CTL & {$[42,48]$} \\
\hline$\alpha$ CTLA4 & CTLA-4 receptor & Immune checkpoint blockade & [55] \\
\hline$\alpha \mathrm{PD}-1$ or $\alpha \mathrm{PD}-\mathrm{L} 1$ & PD-1/PDL-1 & Immune checkpoint blockade & [58] \\
\hline $\begin{array}{l}\text { PD-L1 } \\
\text { acetyltransferase inhibitor }\end{array}$ & PD-L1 & $\begin{array}{l}\text { Palmitoylation of PD-L1 stabilizes } \\
\text { intracellular PD-L1 }\end{array}$ & [64] \\
\hline STAT1 or STAT3 inhibitor & STAT1/STAT3 & The heterodimer activates transcription of PD-L1 & [70] \\
\hline shRNA silences Syntenin1 & Syntenin1 & Syntenin1 upregulates PD-L1 & [71] \\
\hline$\alpha$ LAG-3 & LAG-3 & Immune checkpoint blockade & [91] \\
\hline$\alpha$ TIM-3 & TIM-3 & Immune checkpoint blockade & {$[99,100]$} \\
\hline miR-149-3p mimic & TIM-3 & miR149-3p downregulates PD-1 and TIM-3 & [106] \\
\hline$\alpha$ LLT1 & LLT1 & $\begin{array}{l}\text { LLT1 is a tumor ligand to engage inhibitory } \\
\text { receptors on NK cells }\end{array}$ & [116] \\
\hline 519a-3p antagonist & $\begin{array}{l}\text { Enhances ULBP2 } \\
\& \text { MICA expression }\end{array}$ & Reinstate recognition of $\mathrm{BC}$ by NK cells & [120] \\
\hline $\begin{array}{l}\alpha \mathrm{CD} 24, \alpha \mathrm{CD} 47, \alpha \mathrm{SIRPA}, \\
\alpha \text { Siglec }-10\end{array}$ & CD24, CD47, SIRPA, Siglec-10 & Impede bindings between $\mathrm{BC}$ cells and M2 & [150] \\
\hline$\alpha \mathrm{B} 7-\mathrm{H} 3$ & B7-H3 & $\begin{array}{l}\text { B7-H3 is an immune checkpoint modulator on } \\
\text { tumor cells and TAMs }\end{array}$ & [155] \\
\hline$\alpha$ Mertk & Mertk & Mertk is an immunosuppressive receptor on TAMs & [156] \\
\hline Syndecan 2 peptide & Syndecan-2 & $\begin{array}{l}\text { Syndecan-2 secreted by the stroma } \\
\text { is immunosuppressive }\end{array}$ & [182] \\
\hline Galectin inhibitor & Galectin-3 & $\begin{array}{l}\text { Galectin-3 produced by tumor cells inactivates } \\
\text { multiple glycosylated cytokines and chemokines }\end{array}$ & [184] \\
\hline MEK inhibitor & Ras/MAPK pathway & $\begin{array}{l}\text { Overactivated MAPK pathway is } \\
\text { immunosuppressive }\end{array}$ & [186] \\
\hline GPR81 blockade & GPR81 & $\begin{array}{l}\text { Lactate enhances expression of PD-L1 through the } \\
\text { GPR81 receptor }\end{array}$ & [206] \\
\hline A2a inhibitor & $\mathrm{A} 2 \mathrm{a}$ & $\begin{array}{l}\text { Adenosine inhibits } C T L \text { and } N K \text { through membrane } \\
\text { receptors such as } \mathrm{A} 2 \mathrm{a} \text { and } \mathrm{A} 2 \mathrm{~b}\end{array}$ & {$[215,216]$} \\
\hline HIF-1 inhibitor & HIF & HIF has broad immunosuppressive activities & [222] \\
\hline
\end{tabular}




\begin{abstract}
Author Contributions: Writing—original draft preparation and editing, H.-J.L., D.L. and Y.L. Graphic conception, drawing and editing, H.-J.L. and Y.L. Overall supervision, H.-J.L. and J.L. All authors have read and agreed to the published version of the manuscript.
\end{abstract}

Funding: This study is partly funded by the awarded grants stated in the acknowledgements section.

Acknowledgments: This work is partly supported by an award from the American Cancer Society, grants from Breast Cancer Idea Award Department of Defense (BC073892) and from Susan G. Komen Breast Cancer Foundation (KG081123) to Huey-Jen Lin, as well as by the University of Maryland School of Medicine and Comprehensive Cancer Center start-up fund and CDMRP Breast Cancer Research Program award (W81XWH2010045) to Jiayuh Lin.

Conflicts of Interest: The authors declare no conflict of interest.

\title{
References
}

1. Sung, H.; Ferlay, J.; Siegel, R.L.; Laversanne, M.; Soerjomataram, I.; Jemal, A.; Bray, F. Global Cancer Statistics 2020: GLOBOCAN Estimates of Incidence and Mortality Worldwide for 36 Cancers in 185 Countries. CA Cancer J. Clin. 2021, 71, 209-249. [CrossRef]

2. Hammerl, D.; Smid, M.; Timmermans, A.M.; Sleijfer, S.; Martens, J.W.M.; Debets, R. Breast cancer genomics and immunooncological markers to guide immune therapies. Semin. Cancer Biol. 2018, 52, 178-188. [CrossRef]

3. Prat, A.; Cheang, M.C.; Martin, M.; Parker, J.S.; Carrasco, E.; Caballero, R.; Tyldesley, S.; Gelmon, K.; Bernard, P.S.; Nielsen, T.O.; et al. Prognostic significance of progesterone receptor-positive tumor cells within immunohistochemically defined luminal A breast cancer. J. Clin. Oncol. 2013, 31, 203-209. [CrossRef] [PubMed]

4. Ibrahim, E.; Al-Gahmi, A.M.; Zeenelin, A.A.; Zekri, J.M.; Elkhodary, T.R.; Gaballa, H.E.; Fawzy, E.E.; El Sayed, M.E.; Alzahrani, M.S. Basal vs. luminal A breast cancer subtypes: A matched case-control study using estrogen receptor, progesterone receptor, and HER-2 as surrogate markers. Med. Oncol. 2009, 26, 372-378. [CrossRef]

5. Mehta, R.J.; Jain, R.K.; Leung, S.; Choo, J.; Nielsen, T.; Huntsman, D.; Nakshatri, H.; Badve, S. FOXA1 is an independent prognostic marker for ER-positive breast cancer. Breast Cancer Res. Treat. 2012, 131, 881-890. [CrossRef]

6. Prat, A.; Pineda, E.; Adamo, B.; Galvan, P.; Fernandez, A.; Gaba, L.; Diez, M.; Viladot, M.; Arance, A.; Munoz, M. Clinical implications of the intrinsic molecular subtypes of breast cancer. Breast 2015, 24 (Suppl. 2), S26-S35. [CrossRef] [PubMed]

7. Gadi, V.K.; Davidson, N.E. Practical Approach to Triple-Negative Breast Cancer. J. Oncol. Pract. 2017, 13, 293-300. [CrossRef] [PubMed]

8. Stanton, S.E.; Adams, S.; Disis, M.L. Variation in the Incidence and Magnitude of Tumor-Infiltrating Lymphocytes in Breast Cancer Subtypes: A Systematic Review. JAMA Oncol. 2016, 2, 1354-1360. [CrossRef]

9. Restifo, N.P.; Dudley, M.E.; Rosenberg, S.A. Adoptive immunotherapy for cancer: Harnessing the T cell response. Nat. Rev. Immunol. 2012, 12, 269-281. [CrossRef]

10. Kumar, V.; Patel, S.; Tcyganov, E.; Gabrilovich, D.I. The Nature of Myeloid-Derived Suppressor Cells in the Tumor Microenvironment. Trends Immunol. 2016, 37, 208-220. [CrossRef]

11. Marcus, A.; Gowen, B.G.; Thompson, T.W.; Iannello, A.; Ardolino, M.; Deng, W.; Wang, L.; Shifrin, N.; Raulet, D.H. Recognition of tumors by the innate immune system and natural killer cells. Adv. Immunol. 2014, 122, 91-128.

12. Mittal, D.; Gubin, M.M.; Schreiber, R.D.; Smyth, M.J. New insights into cancer immunoediting and its three component phaseselimination, equilibrium and escape. Curr. Opin. Immunol. 2014, 27, 16-25. [CrossRef]

13. Lim, B.; Woodward, W.A.; Wang, X.; Reuben, J.M.; Ueno, N.T. Inflammatory breast cancer biology: The tumour microenvironment is key. Nat. Rev. Cancer 2018, 18, 485-499. [CrossRef] [PubMed]

14. Joffre, O.P.; Segura, E.; Savina, A.; Amigorena, S. Cross-presentation by dendritic cells. Nat. Rev. Immunol. 2012, 12, 557-569. [CrossRef]

15. Fehres, C.M.; Unger, W.W.; Garcia-Vallejo, J.J.; van Kooyk, Y. Understanding the biology of antigen cross-presentation for the design of vaccines against cancer. Front. Immunol. 2014, 5, 149. [CrossRef]

16. Vinay, D.S.; Ryan, E.P.; Pawelec, G.; Talib, W.H.; Stagg, J.; Elkord, E.; Lichtor, T.; Decker, W.K.; Whelan, R.L.; Kumara, H.; et al. Immune evasion in cancer: Mechanistic basis and therapeutic strategies. Semin. Cancer Biol. 2015, 35, S185-S198. [CrossRef] [PubMed]

17. Bates, J.P.; Derakhshandeh, R.; Jones, L.; Webb, T.J. Mechanisms of immune evasion in breast cancer. BMC Cancer 2018, $18,556$. [CrossRef]

18. Smyth, M.J.; Dunn, G.P.; Schreiber, R.D. Cancer immunosurveillance and immunoediting: The roles of immunity in suppressing tumor development and shaping tumor immunogenicity. Adv. Immunol. 2006, 90, 1-50. [PubMed]

19. Spranger, S.; Sivan, A.; Corrales, L.; Gajewski, T.F. Tumor and Host Factors Controlling Antitumor Immunity and Efficacy of Cancer Immunotherapy. Adv. Immunol. 2016, 130, 75-93. [PubMed]

20. Vesely, M.D.; Kershaw, M.H.; Schreiber, R.D.; Smyth, M.J. Natural innate and adaptive immunity to cancer. Annu. Rev. Immunol. 2011, 29, 235-271. [CrossRef]

21. Schreiber, R.D.; Old, L.J.; Smyth, M.J. Cancer immunoediting: Integrating immunity's roles in cancer suppression and promotion. Science 2011, 331, 1565-1570. [CrossRef] 
22. Forero, A.; Li, Y.; Chen, D.; Grizzle, W.E.; Updike, K.L.; Merz, N.D.; Downs-Kelly, E.; Burwell, T.C.; Vaklavas, C.; Buchsbaum, D.J.; et al. Expression of the MHC Class II Pathway in Triple-Negative Breast Cancer Tumor Cells Is Associated with a Good Prognosis and Infiltrating Lymphocytes. Cancer Immunol. Res. 2016, 4, 390-399. [CrossRef] [PubMed]

23. Leone, P.; Shin, E.C.; Perosa, F.; Vacca, A.; Dammacco, F.; Racanelli, V. MHC class I antigen processing and presenting machinery: Organization, function, and defects in tumor cells. J. Natl. Cancer Inst. 2013, 105, 1172-1187. [CrossRef] [PubMed]

24. Wang, R.F.; Wang, H.Y. Immune targets and neoantigens for cancer immunotherapy and precision medicine. Cell Res. 2017, 27, 11-37. [CrossRef] [PubMed]

25. de Marco, M.C.; Martin-Belmonte, F.; Kremer, L.; Albar, J.P.; Correas, I.; Vaerman, J.P.; Marazuela, M.; Byrne, J.A.; Alonso, M.A MAL2, a novel raft protein of the MAL family, is an essential component of the machinery for transcytosis in hepatoma HepG2 cells. J. Cell Biol. 2002, 159, 37-44. [CrossRef] [PubMed]

26. Fang, Y.; Wang, L.; Wan, C.; Sun, Y.; Van der Jeught, K.; Zhou, Z.; Dong, T.; So, K.M.; Yu, T.; Li, Y.; et al. MAL2 drives immune evasion in breast cancer by suppressing tumor antigen presentation. J. Clin. Investig. 2021, 131, e140837. [CrossRef]

27. Vitale, M.; Rezzani, R.; Rodella, L.; Zauli, G.; Grigolato, P.; Cadei, M.; Hicklin, D.J.; Ferrone, S. HLA class I antigen and transporter associated with antigen processing (TAP1 and TAP2) down-regulation in high-grade primary breast carcinoma lesions. Cancer Res. 1998, 58, 737-742. [PubMed]

28. Chen, H.L.; Gabrilovich, D.; Virmani, A.; Ratnani, I.; Girgis, K.R.; Nadaf-Rahrov, S.; Fernandez-Vina, M.; Carbone, D.P. Structural and functional analysis of beta2 microglobulin abnormalities in human lung and breast cancer. Int. J. Cancer 1996, 67, 756-763. [CrossRef]

29. Nomura, T.; Huang, W.C.; Zhau, H.E.; Josson, S.; Mimata, H.; Chung, L.W. beta2-Microglobulin-mediated signaling as a target for cancer therapy. Anticancer Agents Med. Chem. 2014, 14, 343-352. [CrossRef]

30. Kaneko, K.; Ishigami, S.; Kijima, Y.; Funasako, Y.; Hirata, M.; Okumura, H.; Shinchi, H.; Koriyama, C.; Ueno, S.; Yoshinaka, H.; et al. Clinical implication of HLA class I expression in breast cancer. BMC Cancer 2011, 11, 454. [CrossRef]

31. da Silva, G.B.; Silva, T.G.; Duarte, R.A.; Neto, N.L.; Carrara, H.H.; Donadi, E.A.; Goncalves, M.A.; Soares, E.G.; Soares, C.P Expression of the Classical and Nonclassical HLA Molecules in Breast Cancer. Int. J. Breast Cancer 2013, 2013, 250435. [CrossRef]

32. Harada, A.; Ishigami, S.; Kijima, Y.; Nakajo, A.; Arigami, T.; Kurahara, H.; Kita, Y.; Yoshinaka, H.; Natsugoe, S. Clinical implication of human leukocyte antigen (HLA)-F expression in breast cancer. Pathol. Int. 2015, 65, 569-574. [CrossRef]

33. Konig, L.; Kasimir-Bauer, S.; Hoffmann, O.; Bittner, A.K.; Wagner, B.; Manvailer, L.F.; Schramm, S.; Bankfalvi, A.; Giebel, B.; Kimmig, R.; et al. The prognostic impact of soluble and vesicular HLA-G and its relationship to circulating tumor cells in neoadjuvant treated breast cancer patients. Hum. Immunol. 2016, 77, 791-799. [CrossRef]

34. De Kruijf, E.M.; Engels, C.C.; van de Water, W.; Bastiaannet, E.; Smit, V.T.; van de Velde, C.J.; Liefers, G.J.; Kuppen, P.J. Tumor immune subtypes distinguish tumor subclasses with clinical implications in breast cancer patients. Breast Cancer Res. Treat. 2013, 142, 355-364. [CrossRef] [PubMed]

35. Engels, C.C.; Fontein, D.B.; Kuppen, P.J.; de Kruijf, E.M.; Smit, V.T.; Nortier, J.W.; Liefers, G.J.; van de Velde, C.J.; Bastiaannet, E. Immunological subtypes in breast cancer are prognostic for invasive ductal but not for invasive lobular breast carcinoma. Br. J. Cancer 2014, 111, 532-538. [CrossRef]

36. Lin, A.; Yan, W.H. Human Leukocyte Antigen-G (HLA-G) Expression in Cancers: Roles in Immune Evasion, Metastasis and Target for Therapy. Mol. Med. 2015, 21, 782-791. [CrossRef]

37. Tao, S.; He, H.; Chen, Q.; Yue, W. GPER mediated estradiol reduces miR-148a to promote HLA-G expression in breast cancer. Biochem. Biophys. Res. Commun. 2014, 451, 74-78. [CrossRef]

38. Sheu, J.; Shih Ie, M. HLA-G and immune evasion in cancer cells. J. Formos. Med. Assoc. 2010, 109, 248-257. [CrossRef]

39. Garg, A.D.; More, S.; Rufo, N.; Mece, O.; Sassano, M.L.; Agostinis, P.; Zitvogel, L.; Kroemer, G.; Galluzzi, L. Trial watch: Immunogenic cell death induction by anticancer chemotherapeutics. Oncoimmunology 2017, 6, e1386829. [CrossRef]

40. Adams, S.; Gray, R.J.; Demaria, S.; Goldstein, L.; Perez, E.A.; Shulman, L.N.; Martino, S.; Wang, M.; Jones, V.E.; Saphner, T.J.; et al Prognostic value of tumor-infiltrating lymphocytes in triple-negative breast cancers from two phase III randomized adjuvant breast cancer trials: ECOG 2197 and ECOG 1199. J. Clin. Oncol. 2014, 32, 2959-2966. [CrossRef] [PubMed]

41. Chatterjee, S.; Chatterjee, A.; Jana, S.; Dey, S.; Roy, H.; Das, M.K.; Alam, J.; Adhikary, A.; Chowdhury, A.; Biswas, A.; et al. Transforming growth factor beta orchestrates PD-L1 enrichment in tumor-derived exosomes and mediates CD8 T-cell dysfunction regulating early phosphorylation of TCR signalome in breast cancer. Carcinogenesis 2021, 42, 38-47. [CrossRef]

42. Yamashita, N.; Long, M.; Fushimi, A.; Yamamoto, M.; Hata, T.; Hagiwara, M.; Bhattacharya, A.; Hu, Q.; Wong, K.K.; Liu, S.; et al. MUC1-C integrates activation of the IFN-gamma pathway with suppression of the tumor immune microenvironment in triplenegative breast cancer. J. Immunother. Cancer 2021, 9, e002115. [CrossRef]

43. Steven, A.; Seliger, B. The Role of Immune Escape and Immune Cell Infiltration in Breast Cancer. Breast Care 2018, 13, 16-21. [CrossRef]

44. Chen, L.; Diao, L.; Yang, Y.; Yi, X.; Rodriguez, B.L.; Li, Y.; Villalobos, P.A.; Cascone, T.; Liu, X.; Tan, L.; et al. CD38-Mediated Immunosuppression as a Mechanism of Tumor Cell Escape from PD-1/PD-L1 Blockade. Cancer Discov. 2018, 8, 1156-1175. [CrossRef]

45. Bagati, A.; Kumar, S.; Jiang, P.; Pyrdol, J.; Zou, A.E.; Godicelj, A.; Mathewson, N.D.; Cartwright, A.N.R.; Cejas, P.; Brown, M.; et al. Integrin alphavbeta6-TGFbeta-SOX4 Pathway Drives Immune Evasion in Triple-Negative Breast Cancer. Cancer Cell 2021, 39, 54-67.e59. [CrossRef] 
46. Mojic, M.; Takeda, K.; Hayakawa, Y. The Dark Side of IFN-gamma: Its Role in Promoting Cancer Immunoevasion. Int. J. Mol. Sci. 2017, 19, 89. [CrossRef]

47. Castro, F.; Cardoso, A.P.; Goncalves, R.M.; Serre, K.; Oliveira, M.J. Interferon-Gamma at the Crossroads of Tumor Immune Surveillance or Evasion. Front. Immunol. 2018, 9, 847. [CrossRef]

48. Kufe, D.W. MUC1-C oncoprotein as a target in breast cancer: Activation of signaling pathways and therapeutic approaches. Oncogene 2013, 32, 1073-1081. [CrossRef] [PubMed]

49. Kufe, D.W. MUC1-C in chronic inflammation and carcinogenesis; emergence as a target for cancer treatment. Carcinogenesis 2020, 41, 1173-1183. [CrossRef] [PubMed]

50. Prendergast, G.C.; Malachowski, W.P.; DuHadaway, J.B.; Muller, A.J. Discovery of IDO1 Inhibitors: From Bench to Bedside. Cancer Res. 2017, 77, 6795-6811. [CrossRef] [PubMed]

51. Chikman, B.; Vasyanovich, S.; Lavy, R.; Habler, L.; Tolstov, G.; Kapiev, A.; Halevy, A.; Sandbank, J. COX2 expression in high-grade breast cancer: Evidence for prognostic significance in the subset of triple-negative breast cancer patients. Med. Oncol. 2014, 31, 989. [CrossRef]

52. Wu, A.A.; Drake, V.; Huang, H.S.; Chiu, S.; Zheng, L. Reprogramming the tumor microenvironment: Tumor-induced immunosuppressive factors paralyze T cells. Oncoimmunology 2015, 4, e1016700. [CrossRef]

53. Swoboda, A.; Nanda, R. Immune Checkpoint Blockade for Breast Cancer. Cancer Treat. Res. 2018, 173, 155-165.

54. Michel, L.L.; von Au, A.; Mavratzas, A.; Smetanay, K.; Schutz, F.; Schneeweiss, A. Immune Checkpoint Blockade in Patients with Triple-Negative Breast Cancer. Target Oncol. 2020, 15, 415-428. [CrossRef]

55. Sharpe, A.H.; Freeman, G.J. The B7-CD28 superfamily. Nat. Rev. Immunol. 2002, 2, 116-126. [CrossRef] [PubMed]

56. Van Coillie, S.; Wiernicki, B.; Xu, J. Molecular and Cellular Functions of CTLA-4. Adv. Exp. Med. Biol. 2020, 1248, 7-32.

57. Urbano, A.C.; Nascimento, C.; Soares, M.; Correia, J.; Ferreira, F. Clinical Relevance of the serum CTLA-4 in Cats with Mammary Carcinoma. Sci. Rep. 2020, 10, 3822. [CrossRef] [PubMed]

58. Sharpe, A.H.; Pauken, K.E. The diverse functions of the PD1 inhibitory pathway. Nat. Rev. Immunol. 2018, 18, 153-167. [CrossRef] [PubMed]

59. Muenst, S.; Soysal, S.D.; Gao, F.; Obermann, E.C.; Oertli, D.; Gillanders, W.E. The presence of programmed death 1 (PD-1)-positive tumor-infiltrating lymphocytes is associated with poor prognosis in human breast cancer. Breast Cancer Res. Treat. 2013, 139, 667-676. [CrossRef] [PubMed]

60. Mittendorf, E.A.; Philips, A.V.; Meric-Bernstam, F.; Qiao, N.; Wu, Y.; Harrington, S.; Su, X.; Wang, Y.; Gonzalez-Angulo, A.M.; Akcakanat, A.; et al. PD-L1 expression in triple-negative breast cancer. Cancer Immunol. Res. 2014, 2, 361-370. [CrossRef] [PubMed]

61. Barrett, M.T.; Lenkiewicz, E.; Malasi, S.; Basu, A.; Yearley, J.H.; Annamalai, L.; McCullough, A.E.; Kosiorek, H.E.; Narang, P.; Wilson Sayres, M.A.; et al. The association of genomic lesions and PD-1/PD-L1 expression in resected triple-negative breast cancers. Breast Cancer Res. 2018, 20, 71. [CrossRef]

62. Muenst, S.; Schaerli, A.R.; Gao, F.; Daster, S.; Trella, E.; Droeser, R.A.; Muraro, M.G.; Zajac, P.; Zanetti, R.; Gillanders, W.E.; et al. Expression of programmed death ligand 1 (PD-L1) is associated with poor prognosis in human breast cancer. Breast Cancer Res. Treat. 2014, 146, 15-24. [CrossRef] [PubMed]

63. MuenstMaeda, T.; Hiraki, M.; Jin, C.; Rajabi, H.; Tagde, A.; Alam, M.; Bouillez, A.; Hu, X.; Suzuki, Y.; Miyo, M.; et al. MUC1-C Induces PD-L1 and Immune Evasion in Triple-Negative Breast Cancer. Cancer Res. 2018, 78, 205-215.

64. Yao, H.; Lan, J.; Li, C.; Shi, H.; Brosseau, J.P.; Wang, H.; Lu, H.; Fang, C.; Zhang, Y.; Liang, L.; et al. Inhibiting PD-L1 palmitoylation enhances T-cell immune responses against tumours. Nat. Biomed. Eng. 2019, 3, 306-317. [CrossRef]

65. Nouri, K.; Azad, T.; Lightbody, E.; Khanal, P.; Nicol, C.J.; Yang, X. A kinome-wide screen using a NanoLuc LATS luminescent biosensor identifies ALK as a novel regulator of the Hippo pathway in tumorigenesis and immune evasion. FASEB J. 2019, 33, 12487-12499. [CrossRef]

66. Darvin, P.; Sasidharan Nair, V.; Elkord, E. PD-L1 Expression in Human Breast Cancer Stem Cells Is Epigenetically Regulated through Posttranslational Histone Modifications. J. Oncol. 2019, 2019, 3958908. [CrossRef]

67. Castagnoli, L.; Cancila, V.; Cordoba-Romero, S.L.; Faraci, S.; Talarico, G.; Belmonte, B.; Iorio, M.V.; Milani, M.; Volpari, T.; Chiodoni, C.; et al. WNT signaling modulates PD-L1 expression in the stem cell compartment of triple-negative breast cancer. Oncogene 2019, 38, 4047-4060. [CrossRef] [PubMed]

68. Zhu, H.; Bengsch, F.; Svoronos, N.; Rutkowski, M.R.; Bitler, B.G.; Allegrezza, M.J.; Yokoyama, Y.; Kossenkov, A.V.; Bradner, J.E.; Conejo-Garcia, J.R.; et al. BET Bromodomain Inhibition Promotes Anti-tumor Immunity by Suppressing PD-L1 Expression. Cell Rep. 2016, 16, 2829-2837. [CrossRef] [PubMed]

69. Jing, X.; Shao, S.; Zhang, Y.; Luo, A.; Zhao, L.; Zhang, L.; Gu, S.; Zhao, X. BRD4 inhibition suppresses PD-L1 expression in triple-negative breast cancer. Exp. Cell Res. 2020, 392, 112034. [CrossRef]

70. Sasidharan Nair, V.; Toor, S.M.; Ali, B.R.; Elkord, E. Dual inhibition of STAT1 and STAT3 activation downregulates expression of PD-L1 in human breast cancer cells. Expert Opin. Ther. Targets 2018, 22, 547-557. [CrossRef] [PubMed]

71. Liu, J.; Yang, Y.; Wang, H.; Wang, B.; Zhao, K.; Jiang, W.; Bai, W.; Liu, J.; Yin, J. Syntenin1/MDA-9 (SDCBP) induces immune evasion in triple-negative breast cancer by upregulating PD-L1. Breast Cancer Res. Treat. 2018, 171, 345-357. [CrossRef] [PubMed] 
72. Kumar, S.; Davra, V.; Obr, A.E.; Geng, K.; Wood, T.L.; De Lorenzo, M.S.; Birge, R.B. Crk adaptor protein promotes PD-L1 expression, EMT and immune evasion in a murine model of triple-negative breast cancer. Oncoimmunology 2017, 7, e1376155. [CrossRef] [PubMed]

73. Martinez, V.G.; O’Neill, S.; Salimu, J.; Breslin, S.; Clayton, A.; Crown, J.; O’Driscoll, L. Resistance to HER2-targeted anti-cancer drugs is associated with immune evasion in cancer cells and their derived extracellular vesicles. Oncoimmunology 2017, 6, e1362530. [CrossRef]

74. Timaner, M.; Kotsofruk, R.; Raviv, Z.; Magidey, K.; Shechter, D.; Kan, T.; Nevelsky, A.; Daniel, S.; de Vries, E.G.E.; Zhang, T.; et al. Microparticles from tumors exposed to radiation promote immune evasion in part by PD-L1. Oncogene 2020, 39, 187-203. [CrossRef] [PubMed]

75. Zam, W.; Ali, L. Immune checkpoint inhibitors in the treatment of cancer. Curr. Clin. Pharmacol. 2021. [CrossRef] [PubMed]

76. Alshehri, B. Immunotherapy: New insights in breast cancer treatment. Hum. Antib. 2021, 29, 193-202. [CrossRef]

77. Kwapisz, D. Pembrolizumab and atezolizumab in triple-negative breast cancer. Cancer Immunol. Immunother. 2021, 70, 607-617. [CrossRef]

78. Terranova-Barberio, M.; Thomas, S.; Ali, N.; Pawlowska, N.; Park, J.; Krings, G.; Rosenblum, M.D.; Budillon, A.; Munster, P.N. HDAC inhibition potentiates immunotherapy in triple negative breast cancer. Oncotarget 2017, 8, 114156-114172. [CrossRef] [PubMed]

79. Olino, K.; Park, T.; Ahuja, N. Exposing Hidden Targets: Combining epigenetic and immunotherapy to overcome cancer resistance. Semin. Cancer Biol. 2020, 65, 114-122. [CrossRef]

80. Force, J.; Leal, J.H.S.; McArthur, H.L. Checkpoint Blockade Strategies in the Treatment of Breast Cancer: Where We Are and Where We Are Heading. Curr. Treat. Options Oncol. 2019, 20, 35. [CrossRef]

81. Kang, J.; Demaria, S.; Formenti, S. Current clinical trials testing the combination of immunotherapy with radiotherapy. $J$. Immunother. Cancer 2016, 4, 51. [CrossRef] [PubMed]

82. Pieper, A.A.; Rakhmilevich, A.L.; Spiegelman, D.V.; Patel, R.B.; Birstler, J.; Jin, W.J.; Carlson, P.M.; Charych, D.H.; Hank, J.A.; Erbe, A.K.; et al. Combination of radiation therapy, bempegaldesleukin, and checkpoint blockade eradicates advanced solid tumors and metastases in mice. J. Immunother. Cancer 2021, 9, e002715. [CrossRef]

83. Theelen, W.; Chen, D.; Verma, V.; Hobbs, B.P.; Peulen, H.M.U.; Aerts, J.; Bahce, I.; Niemeijer, A.L.N.; Chang, J.Y.; de Groot, P.M.; et al. Pembrolizumab with or without radiotherapy for metastatic non-small-cell lung cancer: A pooled analysis of two randomised trials. Lancet Respir. Med. 2021, 9, 467-475. [CrossRef]

84. Triebel, F.; Jitsukawa, S.; Baixeras, E.; Roman-Roman, S.; Genevee, C.; Viegas-Pequignot, E.; Hercend, T. LAG-3, a novel lymphocyte activation gene closely related to CD4. J. Exp. Med. 1990, 171, 1393-1405. [CrossRef] [PubMed]

85. Baixeras, E.; Huard, B.; Miossec, C.; Jitsukawa, S.; Martin, M.; Hercend, T.; Auffray, C.; Triebel, F.; Piatier-Tonneau, D. Characterization of the lymphocyte activation gene 3-encoded protein. A new ligand for human leukocyte antigen class II antigens. J. Exp. Med. 1992, 176, 327-337. [CrossRef] [PubMed]

86. Huard, B.; Prigent, P.; Tournier, M.; Bruniquel, D.; Triebel, F. CD4/major histocompatibility complex class II interaction analyzed with CD4- and lymphocyte activation gene-3 (LAG-3)-Ig fusion proteins. Eur. J. Immunol. 1995, 25, 2718-2721. [CrossRef] [PubMed]

87. Wherry, E.J. T cell exhaustion. Nat. Immunol. 2011, 12, 492-499. [CrossRef]

88. Schnorfeil, F.M.; Lichtenegger, F.S.; Emmerig, K.; Schlueter, M.; Neitz, J.S.; Draenert, R.; Hiddemann, W.; Subklewe, M. T cells are functionally not impaired in AML: Increased PD-1 expression is only seen at time of relapse and correlates with a shift towards the memory T cell compartment. J. Hematol. Oncol. 2015, 8, 93. [CrossRef]

89. Matsuzaki, J.; Gnjatic, S.; Mhawech-Fauceglia, P.; Beck, A.; Miller, A.; Tsuji, T.; Eppolito, C.; Qian, F.; Lele, S.; Shrikant, P.; et al. Tumor-infiltrating NY-ESO-1-specific CD8 ${ }^{+} \mathrm{T}$ cells are negatively regulated by LAG-3 and PD-1 in human ovarian cancer. Proc. Natl. Acad. Sci. USA 2010, 107, 7875-7880. [CrossRef]

90. Woo, S.R.; Turnis, M.E.; Goldberg, M.V.; Bankoti, J.; Selby, M.; Nirschl, C.J.; Bettini, M.L.; Gravano, D.M.; Vogel, P.; Liu, C.L.; et al Immune inhibitory molecules LAG-3 and PD-1 synergistically regulate T-cell function to promote tumoral immune escape. Cancer Res. 2012, 72, 917-927. [CrossRef]

91. Lichtenegger, F.S.; Rothe, M.; Schnorfeil, F.M.; Deiser, K.; Krupka, C.; Augsberger, C.; Schluter, M.; Neitz, J.; Subklewe, M. Targeting LAG-3 and PD-1 to Enhance T Cell Activation by Antigen-Presenting Cells. Front. Immunol. 2018, 9, 385. [CrossRef]

92. Kouo, T.; Huang, L.; Pucsek, A.B.; Cao, M.; Solt, S.; Armstrong, T.; Jaffee, E. Galectin-3 Shapes Antitumor Immune Responses by Suppressing CD8 ${ }^{+}$T Cells via LAG-3 and Inhibiting Expansion of Plasmacytoid Dendritic Cells. Cancer Immunol. Res. 2015, 3, 412-423. [CrossRef] [PubMed]

93. Wang, J.; Sanmamed, M.F.; Datar, I.; Su, T.T.; Ji, L.; Sun, J.; Chen, L.; Chen, Y.; Zhu, G.; Yin, W.; et al. Fibrinogen-like Protein 1 Is a Major Immune Inhibitory Ligand of LAG-3. Cell 2019, 176, 334-347.e312. [CrossRef] [PubMed]

94. Monney, L.; Sabatos, C.A.; Gaglia, J.L.; Ryu, A.; Waldner, H.; Chernova, T.; Manning, S.; Greenfield, E.A.; Coyle, A.J.; Sobel, R.A.; et al. Th1-specific cell surface protein Tim-3 regulates macrophage activation and severity of an autoimmune disease. Nature 2002, 415, 536-541. [CrossRef] [PubMed]

95. Yasinska, I.M.; Sakhnevych, S.S.; Pavlova, L.; Teo Hansen Selno, A.; Teuscher Abeleira, A.M.; Benlaouer, O.; Goncalves Silva, I.; Mosimann, M.; Varani, L.; Bardelli, M.; et al. The Tim-3-Galectin-9 Pathway and Its Regulatory Mechanisms in Human Breast Cancer. Front. Immunol. 2019, 10, 1594. [CrossRef] [PubMed] 
96. Zhu, C.; Anderson, A.C.; Schubart, A.; Xiong, H.; Imitola, J.; Khoury, S.J.; Zheng, X.X.; Strom, T.B.; Kuchroo, V.K. The Tim-3 ligand galectin-9 negatively regulates T helper type 1 immunity. Nat. Immunol. 2005, 6, 1245-1252. [CrossRef]

97. Sabatos-Peyton, C.A.; Nevin, J.; Brock, A.; Venable, J.D.; Tan, D.J.; Kassam, N.; Xu, F.; Taraszka, J.; Wesemann, L.; Pertel, T.; et al Blockade of Tim-3 binding to phosphatidylserine and CEACAM1 is a shared feature of anti-Tim-3 antibodies that have functional efficacy. Oncoimmunology 2018, 7, e1385690. [CrossRef]

98. Fang, J.; Chen, F.; Liu, D.; Gu, F.; Chen, Z.; Wang, Y. Prognostic value of immune checkpoint molecules in breast cancer. Biosci. Rep. 2020, 40, BSR20201054. [CrossRef]

99. de Mingo Pulido, A.; Gardner, A.; Hiebler, S.; Soliman, H.; Rugo, H.S.; Krummel, M.F.; Coussens, L.M.; Ruffell, B. TIM-3 Regulates CD103(+) Dendritic Cell Function and Response to Chemotherapy in Breast Cancer. Cancer Cell 2018, 33, 60-74 e66. [CrossRef]

100. de Mingo Pulido, A.; Hanggi, K.; Celias, D.P.; Gardner, A.; Li, J.; Batista-Bittencourt, B.; Mohamed, E.; Trillo-Tinoco, J.; Osunmakinde, O.; Pena, R.; et al. The inhibitory receptor TIM-3 limits activation of the cGAS-STING pathway in intra-tumoral dendritic cells by suppressing extracellular DNA uptake. Immunity 2021, 54, 1154-1167 e1157. [CrossRef]

101. Gardner, A.; de Mingo Pulido, A.; Ruffell, B. Dendritic Cells and Their Role in Immunotherapy. Front. Immunol. 2020, 11, 924. [CrossRef]

102. Cong, Y.; Cui, Y.; Zhu, S.; Cao, J.; Zou, H.; Martin, T.A.; Qiao, G.; Jiang, W.; Yu, Z. Tim-3 promotes cell aggressiveness and paclitaxel resistance through NF-kappaB/STAT3 signalling pathway in breast cancer cells. Chin. J. Cancer Res. 2020, 32, 564-579. [CrossRef]

103. Liu, Q.; Yu, S.; Li, A.; Xu, H.; Han, X.; Wu, K. Targeting interlukin-6 to relieve immunosuppression in tumor microenvironment. Tumour. Biol. 2017, 39, 1010428317712445. [CrossRef] [PubMed]

104. Wang, Y.; Shen, Y.; Wang, S.; Shen, Q.; Zhou, X. The role of STAT3 in leading the crosstalk between human cancers and the immune system. Cancer Lett. 2018, 415, 117-128. [CrossRef]

105. Cheng, S.; Han, F.; Xu, Y.; Qu, T.; Ju, Y. Expression of Tim-3 in breast cancer tissue promotes tumor progression. Int. J. Clin. Exp. Pathol. 2018, 11, 1157-1166.

106. Zhang, M.; Gao, D.; Shi, Y.; Wang, Y.; Joshi, R.; Yu, Q.; Liu, D.; Alotaibi, F.; Zhang, Y.; Wang, H.; et al. miR-149-3p reverses CD8(+) T-cell exhaustion by reducing inhibitory receptors and promoting cytokine secretion in breast cancer cells. Open Biol. 2019, 9, 190061. [CrossRef]

107. Acharya, N.; Sabatos-Peyton, C.; Anderson, A.C. Tim-3 finds its place in the cancer immunotherapy landscape. J. Immunother. Cancer 2020, 8, e000911. [CrossRef] [PubMed]

108. Ngiow, S.F.; von Scheidt, B.; Akiba, H.; Yagita, H.; Teng, M.W.; Smyth, M.J. Anti-TIM3 antibody promotes T cell IFN-gammamediated antitumor immunity and suppresses established tumors. Cancer Res. 2011, 71, 3540-3551. [CrossRef] [PubMed]

109. Klein, C.; Schaefer, W.; Regula, J.T.; Dumontet, C.; Brinkmann, U.; Bacac, M.; Umana, P. Engineering therapeutic bispecific antibodies using CrossMab technology. Methods 2019, 154, 21-31. [CrossRef]

110. Koyama, S.; Akbay, E.A.; Li, Y.Y.; Herter-Sprie, G.S.; Buczkowski, K.A.; Richards, W.G.; Gandhi, L.; Redig, A.J.; Rodig, S.J.; Asahina, H.; et al. Adaptive resistance to therapeutic PD-1 blockade is associated with upregulation of alternative immune checkpoints. Nat. Commun. 2016, 7, 10501. [CrossRef]

111. Saleh, R.; Toor, S.M.; Khalaf, S.; Elkord, E. Breast Cancer Cells and PD-1/PD-L1 Blockade Upregulate the Expression of PD-1, CTLA-4, TIM-3 and LAG-3 Immune Checkpoints in CD4(+) T Cells. Vaccines 2019, 7, 149. [CrossRef] [PubMed]

112. Saleh, R.; Elkord, E. Treg-mediated acquired resistance to immune checkpoint inhibitors. Cancer Lett. 2019, 457, 168-179. [CrossRef] [PubMed]

113. Lopez-Soto, A.; Huergo-Zapico, L.; Acebes-Huerta, A.; Villa-Alvarez, M.; Gonzalez, S. NKG2D signaling in cancer immunosurveillance. Int. J. Cancer 2015, 136, 1741-1750. [CrossRef]

114. Schmiedel, D.; Mandelboim, O. NKG2D Ligands-Critical Targets for Cancer Immune Escape and Therapy. Front. Immunol. 2018, 9, 2040. [CrossRef] [PubMed]

115. Rosen, D.B.; Bettadapura, J.; Alsharifi, M.; Mathew, P.A.; Warren, H.S.; Lanier, L.L. Cutting edge: Lectin-like transcript-1 is a ligand for the inhibitory human NKR-P1A receptor. J. Immunol. 2005, 175, 7796-7799. [CrossRef] [PubMed]

116. Marrufo, A.M.; Mathew, S.O.; Chaudhary, P.; Malaer, J.D.; Vishwanatha, J.K.; Mathew, P.A. Blocking LLT1 (CLEC2D, OCIL)NKRP1A (CD161) interaction enhances natural killer cell-mediated lysis of triple-negative breast cancer cells. Am. J. Cancer Res. 2018, 8, 1050-1063.

117. Mamessier, E.; Sylvain, A.; Thibult, M.L.; Houvenaeghel, G.; Jacquemier, J.; Castellano, R.; Goncalves, A.; Andre, P.; Romagne, F.; Thibault, G.; et al. Human breast cancer cells enhance self tolerance by promoting evasion from NK cell antitumor immunity. $J$. Clin. Investig. 2011, 121, 3609-3622. [CrossRef]

118. Berrien-Elliott, M.M.; Romee, R.; Fehniger, T.A. Improving natural killer cell cancer immunotherapy. Curr. Opin. Organ. Transplant. 2015, 20, 671-680. [CrossRef]

119. Park, I.H.; Yang, H.N.; Lee, K.J.; Kim, T.S.; Lee, E.S.; Jung, S.Y.; Kwon, Y.; Kong, S.Y. Tumor-derived IL-18 induces PD-1 expression on immunosuppressive NK cells in triple-negative breast cancer. Oncotarget 2017, 8, 32722-32730. [CrossRef]

120. Breunig, C.; Pahl, J.; Kublbeck, M.; Miller, M.; Antonelli, D.; Erdem, N.; Wirth, C.; Will, R.; Bott, A.; Cerwenka, A.; et al MicroRNA-519a-3p mediates apoptosis resistance in breast cancer cells and their escape from recognition by natural killer cells. Cell Death Dis. 2017, 8, e2973. [CrossRef] 
121. Fang, D.; Zhu, J. Dynamic balance between master transcription factors determines the fates and functions of CD4 T cell and innate lymphoid cell subsets. J. Exp. Med. 2017, 214, 1861-1876. [CrossRef]

122. Tanaka, A.; Sakaguchi, S. Regulatory T cells in cancer immunotherapy. Cell Res. 2017, 27, 109-118. [CrossRef]

123. Li, Z.; Dong, P.; Ren, M.; Song, Y.; Qian, X.; Yang, Y.; Li, S.; Zhang, X.; Liu, F. PD-L1 Expression Is Associated with Tumor FOXP3(+) Regulatory T-Cell Infiltration of Breast Cancer and Poor Prognosis of Patient. J. Cancer 2016, 7, 784-793. [CrossRef] [PubMed]

124. Takeuchi, Y.; Nishikawa, H. Roles of regulatory T cells in cancer immunity. Int. Immunol. 2016, 28, 401-409. [CrossRef]

125. Bates, G.J.; Fox, S.B.; Han, C.; Leek, R.D.; Garcia, J.F.; Harris, A.L.; Banham, A.H. Quantification of regulatory T cells enables the identification of high-risk breast cancer patients and those at risk of late relapse. J. Clin. Oncol. 2006, 24, 5373-5380. [CrossRef] [PubMed]

126. Shou, J.; Zhang, Z.; Lai, Y.; Chen, Z.; Huang, J. Worse outcome in breast cancer with higher tumor-infiltrating FOXP3+ Tregs: A systematic review and meta-analysis. BMC Cancer 2016, 16, 687. [CrossRef]

127. Chuang, L.S.; Ito, Y. RUNX3 is multifunctional in carcinogenesis of multiple solid tumors. Oncogene 2010, 29, 2605-2615. [CrossRef]

128. Chakraborty, S.; Panda, A.K.; Bose, S.; Roy, D.; Kajal, K.; Guha, D.; Sa, G. Transcriptional regulation of FOXP3 requires integrated activation of both promoter and CNS regions in tumor-induced CD8(+) Treg cells. Sci. Rep. 2017, 7, 1628. [CrossRef]

129. Manandhar, S.; Lee, Y.M. Emerging role of RUNX3 in the regulation of tumor microenvironment. BMB. Rep. 2018, 51, 174-181. [CrossRef] [PubMed]

130. Bohling, S.D.; Allison, K.H. Immunosuppressive regulatory T cells are associated with aggressive breast cancer phenotypes: A potential therapeutic target. Mod. Pathol. 2008, 21, 1527-1532. [CrossRef] [PubMed]

131. Ohara, M.; Yamaguchi, Y.; Matsuura, K.; Murakami, S.; Arihiro, K.; Okada, M. Possible involvement of regulatory T cells in tumor onset and progression in primary breast cancer. Cancer Immunol. Immunother. 2009, 58, 441-447. [CrossRef]

132. Tan, W.; Zhang, W.; Strasner, A.; Grivennikov, S.; Cheng, J.Q.; Hoffman, R.M.; Karin, M. Tumour-infiltrating regulatory T cells stimulate mammary cancer metastasis through RANKL-RANK signalling. Nature 2011, 470, 548-553. [CrossRef] [PubMed]

133. Miyashita, M.; Sasano, H.; Tamaki, K.; Chan, M.; Hirakawa, H.; Suzuki, A.; Tada, H.; Watanabe, G.; Nemoto, N.; Nakagawa, S.; et al. Tumor-infiltrating $\mathrm{CD}^{+}$and FOXP3+ lymphocytes in triple-negative breast cancer: Its correlation with pathological complete response to neoadjuvant chemotherapy. Breast Cancer Res. Treat. 2014, 148, 525-534. [CrossRef] [PubMed]

134. Asano, Y.; Kashiwagi, S.; Goto, W.; Kurata, K.; Noda, S.; Takashima, T.; Onoda, N.; Tanaka, S.; Ohsawa, M.; Hirakawa, K. Tumourinfiltrating CD8 to FOXP3 lymphocyte ratio in predicting treatment responses to neoadjuvant chemotherapy of aggressive breast cancer. Br. J. Surg. 2016, 103, 845-854. [CrossRef] [PubMed]

135. Ladoire, S.; Arnould, L.; Apetoh, L.; Coudert, B.; Martin, F.; Chauffert, B.; Fumoleau, P.; Ghiringhelli, F. Pathologic complete response to neoadjuvant chemotherapy of breast carcinoma is associated with the disappearance of tumor-infiltrating foxp3+ regulatory T cells. Clin. Cancer Res. 2008, 14, 2413-2420. [CrossRef] [PubMed]

136. Georgoudaki, A.M.; Prokopec, K.E.; Boura, V.F.; Hellqvist, E.; Sohn, S.; Ostling, J.; Dahan, R.; Harris, R.A.; Rantalainen, M.; Klevebring, D.; et al. Reprogramming Tumor-Associated Macrophages by Antibody Targeting Inhibits Cancer Progression and Metastasis. Cell Rep. 2016, 15, 2000-2011. [CrossRef]

137. Poh, A.R.; Ernst, M. Targeting Macrophages in Cancer: From Bench to Bedside. Front. Oncol. 2018, 8, 49. [CrossRef] [PubMed]

138. Hao, N.B.; Lu, M.H.; Fan, Y.H.; Cao, Y.L.; Zhang, Z.R.; Yang, S.M. Macrophages in tumor microenvironments and the progression of tumors. Clin. Dev. Immunol. 2012, 2012, 948098. [CrossRef]

139. Wan, S.; Zhao, E.; Kryczek, I.; Vatan, L.; Sadovskaya, A.; Ludema, G.; Simeone, D.M.; Zou, W.; Welling, T.H. Tumor-associated macrophages produce interleukin 6 and signal via STAT3 to promote expansion of human hepatocellular carcinoma stem cells. Gastroenterology 2014, 147, 1393-1404. [CrossRef]

140. Katoh, M. FGFR inhibitors: Effects on cancer cells, tumor microenvironment and whole-body homeostasis (Review). Int. J. Mol. Med. 2016, 38, 3-15. [CrossRef]

141. Ham, S.; Lima, L.G.; Chai, E.P.Z.; Muller, A.; Lobb, R.J.; Krumeich, S.; Wen, S.W.; Wiegmans, A.P.; Moller, A. Breast Cancer-Derived Exosomes Alter Macrophage Polarization via gp130/STAT3 Signaling. Front. Immunol. 2018, 9, 871. [CrossRef] [PubMed]

142. Leek, R.D.; Talks, K.L.; Pezzella, F.; Turley, H.; Campo, L.; Brown, N.S.; Bicknell, R.; Taylor, M.; Gatter, K.C.; Harris, A.L. Relation of hypoxia-inducible factor-2 alpha (HIF-2 alpha) expression in tumor-infiltrative macrophages to tumor angiogenesis and the oxidative thymidine phosphorylase pathway in Human breast cancer. Cancer Res. 2002, 62, 1326-1329.

143. Medrek, C.; Ponten, F.; Jirstrom, K.; Leandersson, K. The presence of tumor associated macrophages in tumor stroma as a prognostic marker for breast cancer patients. BMC Cancer 2012, 12, 306. [CrossRef] [PubMed]

144. Williams, C.B.; Yeh, E.S.; Soloff, A.C. Tumor-associated macrophages: Unwitting accomplices in breast cancer malignancy. NPJ Breast Cancer 2016, 2, 1-12. [CrossRef]

145. Ruffell, B.; Chang-Strachan, D.; Chan, V.; Rosenbusch, A.; Ho, C.M.; Pryer, N.; Daniel, D.; Hwang, E.S.; Rugo, H.S.; Coussens, L.M. Macrophage IL-10 blocks CD8 ${ }^{+} \mathrm{T}$ cell-dependent responses to chemotherapy by suppressing IL-12 expression in intratumoral dendritic cells. Cancer Cell 2014, 26, 623-637. [CrossRef]

146. Gordon, S.R.; Maute, R.L.; Dulken, B.W.; Hutter, G.; George, B.M.; McCracken, M.N.; Gupta, R.; Tsai, J.M.; Sinha, R.; Corey, D.; et al. PD-1 expression by tumour-associated macrophages inhibits phagocytosis and tumour immunity. Nature 2017, 545, 495-499. [CrossRef] 
147. Gok Yavuz, B.; Gunaydin, G.; Gedik, M.E.; Kosemehmetoglu, K.; Karakoc, D.; Ozgur, F.; Guc, D. Cancer associated fibroblasts sculpt tumour microenvironment by recruiting monocytes and inducing immunosuppressive PD-1(+) TAMs. Sci. Rep. 2019, 9, 3172. [CrossRef]

148. Willingham, S.B.; Volkmer, J.P.; Gentles, A.J.; Sahoo, D.; Dalerba, P.; Mitra, S.S.; Wang, J.; Contreras-Trujillo, H.; Martin, R.; Cohen, J.D.; et al. The CD47-signal regulatory protein alpha (SIRPa) interaction is a therapeutic target for human solid tumors. Proc. Natl. Acad. Sci. USA 2012, 109, 6662-6667. [CrossRef]

149. McCracken, M.N.; Cha, A.C.; Weissman, I.L. Molecular Pathways: Activating T Cells after Cancer Cell Phagocytosis from Blockade of CD47 “Don't Eat Me” Signals. Clin. Cancer Res. 2015, 21, 3597-3601. [CrossRef]

150. Barkal, A.A.; Brewer, R.E.; Markovic, M.; Kowarsky, M.; Barkal, S.A.; Zaro, B.W.; Krishnan, V.; Hatakeyama, J.; Dorigo, O.; Barkal, L.J.; et al. CD24 signalling through macrophage Siglec-10 is a target for cancer immunotherapy. Nature 2019, 572, 392-396. [CrossRef] [PubMed]

151. Zhang, M.; Yan, L.; Kim, J.A. Modulating mammary tumor growth, metastasis and immunosuppression by siRNA-induced MIF reduction in tumor microenvironment. Cancer Gene Ther. 2015, 22, 463-474. [CrossRef]

152. Charan, M.; Das, S.; Mishra, S.; Chatterjee, N.; Varikuti, S.; Kaul, K.; Misri, S.; Ahirwar, D.K.; Satoskar, A.R.; Ganju, R.K. Macrophage migration inhibitory factor inhibition as a novel therapeutic approach against triple-negative breast cancer. Cell Death Dis. 2020, 11, 774. [CrossRef] [PubMed]

153. Picarda, E.; Ohaegbulam, K.C.; Zang, X. Molecular Pathways: Targeting B7-H3 (CD276) for Human Cancer Immunotherapy. Clin. Cancer Res. 2016, 22, 3425-3431. [CrossRef] [PubMed]

154. Cheng, N.; Bei, Y.; Song, Y.; Zhang, W.; Xu, L.; Zhang, W.; Yang, N.; Bai, X.; Shu, Y.; Shen, P. B7-H3 augments the pro-angiogenic function of tumor-associated macrophages and acts as a novel adjuvant target for triple-negative breast cancer therapy. Biochem. Pharmacol. 2021, 183, 114298. [CrossRef] [PubMed]

155. Lee, Y.H.; Martin-Orozco, N.; Zheng, P.; Li, J.; Zhang, P.; Tan, H.; Park, H.J.; Jeong, M.; Chang, S.H.; Kim, B.S.; et al. Inhibition of the B7-H3 immune checkpoint limits tumor growth by enhancing cytotoxic lymphocyte function. Cell Res. 2017, 27, 1034-1045. [CrossRef] [PubMed]

156. Davra, V.; Kumar, S.; Geng, K.; Calianese, D.; Mehta, D.; Gadiyar, V.; Kasikara, C.; Lahey, K.C.; Chang, Y.J.; Wichroski, M.; et al. Axl and Mertk Receptors Cooperate to Promote Breast Cancer Progression by Combined Oncogenic Signaling and Evasion of Host Antitumor Immunity. Cancer Res. 2021, 81, 698-712. [CrossRef]

157. De Cicco, P.; Ercolano, G.; Ianaro, A. The New Era of Cancer Immunotherapy: Targeting Myeloid-Derived Suppressor Cells to Overcome Immune Evasion. Front. Immunol. 2020, 11, 1680. [CrossRef] [PubMed]

158. Bergenfelz, C.; Larsson, A.M.; von Stedingk, K.; Gruvberger-Saal, S.; Aaltonen, K.; Jansson, S.; Jernstrom, H.; Janols, H.; Wullt, M.; Bredberg, A.; et al. Systemic Monocytic-MDSCs Are Generated from Monocytes and Correlate with Disease Progression in Breast Cancer Patients. PLoS ONE 2015, 10, e0127028. [CrossRef]

159. Morales, J.K.; Kmieciak, M.; Knutson, K.L.; Bear, H.D.; Manjili, M.H. GM-CSF is one of the main breast tumor-derived soluble factors involved in the differentiation of CD11b-Gr1- bone marrow progenitor cells into myeloid-derived suppressor cells. Breast Cancer Res Treat. 2010, 123, 39-49. [CrossRef]

160. Shou, D.; Wen, L.; Song, Z.; Yin, J.; Sun, Q.; Gong, W. Suppressive role of myeloid-derived suppressor cells (MDSCs) in the microenvironment of breast cancer and targeted immunotherapies. Oncotarget 2016, 7, 64505-64511. [CrossRef]

161. Groth, C.; Hu, X.; Weber, R.; Fleming, V.; Altevogt, P.; Utikal, J.; Umansky, V. Immunosuppression mediated by myeloid-derived suppressor cells (MDSCs) during tumour progression. Br. J. Cancer 2019, 120, 16-25. [CrossRef] [PubMed]

162. Ugel, S.; De Sanctis, F.; Mandruzzato, S.; Bronte, V. Tumor-induced myeloid deviation: When myeloid-derived suppressor cells meet tumor-associated macrophages. J. Clin. Investig. 2015, 125, 3365-3376. [CrossRef]

163. Veglia, F.; Perego, M.; Gabrilovich, D. Myeloid-derived suppressor cells coming of age. Nat. Immunol. 2018, 19, 108-119. [CrossRef]

164. Gantt, S.; Gervassi, A.; Jaspan, H.; Horton, H. The role of myeloid-derived suppressor cells in immune ontogeny. Front. Immunol. 2014, 5, 387. [CrossRef]

165. Guo, Q.; Lv, Z.; Fu, Q.; Jiang, C.; Liu, Y.; Lai, L.; Chen, Q.; Shen, J.; Wang, Q. IFN-gamma producing T cells contribute to the increase of myeloid derived suppressor cells in tumor-bearing mice after cyclophosphamide treatment. Int. Immunopharmacol. 2012, 12, 425-432. [CrossRef] [PubMed]

166. Huang, J.; Jochems, C.; Talaie, T.; Anderson, A.; Jales, A.; Tsang, K.Y.; Madan, R.A.; Gulley, J.L.; Schlom, J. Elevated serum soluble CD40 ligand in cancer patients may play an immunosuppressive role. Blood 2012, 120, 3030-3038. [CrossRef] [PubMed]

167. Noman, M.Z.; Desantis, G.; Janji, B.; Hasmim, M.; Karray, S.; Dessen, P.; Bronte, V.; Chouaib, S. PD-L1 is a novel direct target of HIF-1alpha, and its blockade under hypoxia enhanced MDSC-mediated T cell activation. J. Exp. Med. 2014, 211, 781-790. [CrossRef]

168. Ma, H.S.; Poudel, B.; Torres, E.R.; Sidhom, J.W.; Robinson, T.M.; Christmas, B.; Scott, B.; Cruz, K.; Woolman, S.; Wall, V.Z.; et al. A CD40 Agonist and PD-1 Antagonist Antibody Reprogram the Microenvironment of Nonimmunogenic Tumors to Allow T-cell-Mediated Anticancer Activity. Cancer Immunol. Res. 2019, 7, 428-442. [CrossRef]

169. Song, X.; Krelin, Y.; Dvorkin, T.; Bjorkdahl, O.; Segal, S.; Dinarello, C.A.; Voronov, E.; Apte, R.N. CD11b+/Gr-1+ immature myeloid cells mediate suppression of T cells in mice bearing tumors of IL-1beta-secreting cells. J. Immunol. 2005, 175, 8200-8208. [CrossRef] 
170. Bunt, S.K.; Sinha, P.; Clements, V.K.; Leips, J.; Ostrand-Rosenberg, S. Inflammation induces myeloid-derived suppressor cells that facilitate tumor progression. J. Immunol. 2006, 176, 284-290. [CrossRef]

171. Sinha, P.; Clements, V.K.; Fulton, A.M.; Ostrand-Rosenberg, S. Prostaglandin E2 promotes tumor progression by inducing myeloid-derived suppressor cells. Cancer Res. 2007, 67, 4507-4513. [CrossRef] [PubMed]

172. Cheng, R.; Billet, S.; Liu, C.; Haldar, S.; Choudhury, D.; Tripathi, M.; Hav, M.; Merchant, A.; Hu, T.; Huang, H.; et al. Periodontal inflammation recruits distant metastatic breast cancer cells by increasing myeloid-derived suppressor cells. Oncogene 2020, 39, 1543-1556. [CrossRef]

173. Smith, A.D.; Lu, C.; Payne, D.; Paschall, A.V.; Klement, J.D.; Redd, P.S.; Ibrahim, M.L.; Yang, D.; Han, Q.; Liu, Z.; et al. Autocrine IL6-Mediated Activation of the STAT3-DNMT Axis Silences the TNFalpha-RIP1 Necroptosis Pathway to Sustain Survival and Accumulation of Myeloid-Derived Suppressor Cells. Cancer Res. 2020, 80, 3145-3156. [CrossRef]

174. Weber, R.; Groth, C.; Lasser, S.; Arkhypov, I.; Petrova, V.; Altevogt, P.; Utikal, J.; Umansky, V. IL-6 as a major regulator of MDSC activity and possible target for cancer immunotherapy. Cell Immunol. 2021, 359, 104254. [CrossRef] [PubMed]

175. Munn, D.H. Blocking IDO activity to enhance anti-tumor immunity. Front. Biosci. 2012, 4, 734-745. [CrossRef]

176. Shojaei, F.; Wu, X.; Qu, X.; Kowanetz, M.; Yu, L.; Tan, M.; Meng, Y.G.; Ferrara, N. G-CSF-initiated myeloid cell mobilization and angiogenesis mediate tumor refractoriness to anti-VEGF therapy in mouse models. Proc. Natl. Acad. Sci. USA 2009, 106, 6742-6747. [CrossRef]

177. Li, W.; Tanikawa, T.; Kryczek, I.; Xia, H.; Li, G.; Wu, K.; Wei, S.; Zhao, L.; Vatan, L.; Wen, B.; et al. Aerobic Glycolysis Controls Myeloid-Derived Suppressor Cells and Tumor Immunity via a Specific CEBPB Isoform in Triple-Negative Breast Cancer. Cell Metab. 2018, 28, 87-103 e106. [CrossRef]

178. Kumar, S.; Wilkes, D.W.; Samuel, N.; Blanco, M.A.; Nayak, A.; Alicea-Torres, K.; Gluck, C.; Sinha, S.; Gabrilovich, D.; Chakrabarti, R. DeltaNp63-driven recruitment of myeloid-derived suppressor cells promotes metastasis in triple-negative breast cancer. J. Clin. Investig. 2018, 128, 5095-5109. [CrossRef]

179. Chouaib, S.; Janji, B.; Tittarelli, A.; Eggermont, A.; Thiery, J.P. Tumor plasticity interferes with anti-tumor immunity. Crit. Rev. Immunol. 2014, 34, 91-102. [CrossRef]

180. You, F.P.; Zhang, J.; Cui, T.; Zhu, R.; Lv, C.Q.; Tang, H.T.; Sun, D.W. Th9 cells promote antitumor immunity via IL-9 and IL-21 and demonstrate atypical cytokine expression in breast cancer. Int. Immunopharmacol. 2017, 52, 163-167. [CrossRef]

181. Wu, S.Z.; Roden, D.L.; Wang, C.; Holliday, H.; Harvey, K.; Cazet, A.S.; Murphy, K.J.; Pereira, B.; Al-Eryani, G.; Bartonicek, N.; et al Stromal cell diversity associated with immune evasion in human triple-negative breast cancer. EMBO J. 2020, 39 , e104063. [CrossRef]

182. Loftus, P.G.; Watson, L.; Deedigan, L.M.; Camarillo-Retamosa, E.; Dwyer, R.M.; O’Flynn, L.; Alagesan, S.; Griffin, M.; O’Brien, T.; Kerin, M.J.; et al. Targeting stromal cell Syndecan-2 reduces breast tumour growth, metastasis and limits immune evasion. Int. J. Cancer 2021, 148, 1245-1259. [CrossRef]

183. Gal, P.; Varinska, L.; Faber, L.; Novak, S.; Szabo, P.; Mitrengova, P.; Mirossay, A.; Mucaji, P.; Smetana, K. How Signaling Molecules Regulate Tumor Microenvironment: Parallels to Wound Repair. Molecules 2017, 22, 1818. [CrossRef] [PubMed]

184. Gordon-Alonso, M.; Hirsch, T.; Wildmann, C.; van der Bruggen, P. Galectin-3 captures interferon-gamma in the tumor matrix reducing chemokine gradient production and T-cell tumor infiltration. Nat. Commun. 2017, 8, 793. [CrossRef]

185. Lindau, D.; Gielen, P.; Kroesen, M.; Wesseling, P.; Adema, G.J. The immunosuppressive tumour network: Myeloid-derived suppressor cells, regulatory T cells and natural killer T cells. Immunology 2013, 138, 105-115. [CrossRef]

186. Loi, S.; Dushyanthen, S.; Beavis, P.A.; Salgado, R.; Denkert, C.; Savas, P.; Combs, S.; Rimm, D.L.; Giltnane, J.M.; Estrada, M.V.; et al RAS/MAPK Activation Is Associated with Reduced Tumor-Infiltrating Lymphocytes in Triple-Negative Breast Cancer: Therapeutic Cooperation Between MEK and PD-1/PD-L1 Immune Checkpoint Inhibitors. Clin. Cancer Res. 2016, 22, 1499-1509. [CrossRef] [PubMed]

187. Franklin, D.A.; James, J.L.; Axelrod, M.L.; Balko, J.M. MEK inhibition activates STAT signaling to increase breast cancer immunogenicity via MHC-I expression. Cancer Drug. Resist. 2020, 3, 603-612. [CrossRef]

188. Campesato, L.F.; Silva, A.P.M.; Cordeiro, L.; Correa, B.R.; Navarro, F.C.P.; Zanin, R.F.; Marcola, M.; Inoue, L.T.; Duarte, M.L.; Molgora, M.; et al. High IL-1R8 expression in breast tumors promotes tumor growth and contributes to impaired antitumor immunity. Oncotarget 2017, 8, 49470-49483. [CrossRef] [PubMed]

189. Garlanda, C.; Dinarello, C.A.; Mantovani, A. The interleukin-1 family: Back to the future. Immunity 2013, 39, 1003-1018. [CrossRef]

190. Fuertes, M.B.; Woo, S.R.; Burnett, B.; Fu, Y.X.; Gajewski, T.F. Type I interferon response and innate immune sensing of cancer. Trends Immunol. 2013, 34, 67-73. [CrossRef]

191. Garlanda, C.; Anders, H.J.; Mantovani, A. TIR8/SIGIRR: An IL-1R/TLR family member with regulatory functions in inflammation and T cell polarization. Trends Immunol. 2009, 30, 439-446. [CrossRef] [PubMed]

192. Wald, D.; Qin, J.; Zhao, Z.; Qian, Y.; Naramura, M.; Tian, L.; Towne, J.; Sims, J.E.; Stark, G.R.; Li, X. SIGIRR, a negative regulator of Toll-like receptor-interleukin 1 receptor signaling. Nat. Immunol. 2003, 4, 920-927. [CrossRef] [PubMed]

193. Qin, J.; Qian, Y.; Yao, J.; Grace, C.; Li, X. SIGIRR inhibits interleukin-1 receptor- and toll-like receptor 4-mediated signaling through different mechanisms. J. Biol. Chem. 2005, 280, 25233-25241. [CrossRef]

194. Wegiel, B.; Vuerich, M.; Daneshmandi, S.; Seth, P. Metabolic Switch in the Tumor Microenvironment Determines Immune Responses to Anti-cancer Therapy. Front. Oncol. 2018, 8, 284. [CrossRef] 
195. Hayes, C.; Donohoe, C.L.; Davern, M.; Donlon, N.E. The oncogenic and clinical implications of lactate induced immunosuppression in the tumour microenvironment. Cancer Lett. 2021, 500, 75-86. [CrossRef]

196. Singer, K.; Kastenberger, M.; Gottfried, E.; Hammerschmied, C.G.; Buttner, M.; Aigner, M.; Seliger, B.; Walter, B.; Schlosser, H.; Hartmann, A.; et al. Warburg phenotype in renal cell carcinoma: High expression of glucose-transporter 1 (GLUT-1) correlates with low CD8(+) T-cell infiltration in the tumor. Int. J. Cancer 2011, 128, 2085-2095. [CrossRef]

197. Renner, K.; Singer, K.; Koehl, G.E.; Geissler, E.K.; Peter, K.; Siska, P.J.; Kreutz, M. Metabolic Hallmarks of Tumor and Immune Cells in the Tumor Microenvironment. Front. Immunol. 2017, 8, 248. [CrossRef] [PubMed]

198. Gillies, R.J.; Gatenby, R.A. Metabolism and its sequelae in cancer evolution and therapy. Cancer J. 2015, 21, 88-96. [CrossRef]

199. Fischer, K.; Hoffmann, P.; Voelkl, S.; Meidenbauer, N.; Ammer, J.; Edinger, M.; Gottfried, E.; Schwarz, S.; Rothe, G.; Hoves, S.; et al. Inhibitory effect of tumor cell-derived lactic acid on human T cells. Blood 2007, 109, 3812-3819. [CrossRef]

200. Yuan, C.; Zhang, J.; Lou, J.; Wang, S.; Jiang, Y.; Wu, F.; Wang, S. Comprehensive Analysis of Monocarboxylate Transporter 4 (MCT4) expression in breast cancer prognosis and immune infiltration via integrated bioinformatics analysis. Bioengineered 2021, 12, 3850-3863. [CrossRef]

201. Husain, Z.; Huang, Y.; Seth, P.; Sukhatme, V.P. Tumor-derived lactate modifies antitumor immune response: Effect on myeloidderived suppressor cells and NK cells. J. Immunol. 2013, 191, 1486-1495. [CrossRef]

202. Colegio, O.R.; Chu, N.Q.; Szabo, A.L.; Chu, T.; Rhebergen, A.M.; Jairam, V.; Cyrus, N.; Brokowski, C.E.; Eisenbarth, S.C.; Phillips, G.M.; et al. Functional polarization of tumour-associated macrophages by tumour-derived lactic acid. Nature 2014, 513, 559-563. [CrossRef] [PubMed]

203. Shan, T.; Chen, S.; Chen, X.; Wu, T.; Yang, Y.; Li, S.; Ma, J.; Zhao, J.; Lin, W.; Li, W.; et al. M2TAM subsets altered by lactic acid promote Tcell apoptosis through the PDL1/PD1 pathway. Oncol. Rep. 2020, 44, 1885-1894. [PubMed]

204. Zhou, H.C.; Xin-Yan, Y.; Yu, W.W.; Liang, X.Q.; Du, X.Y.; Liu, Z.C.; Long, J.P.; Zhao, G.H.; Liu, H.B. Lactic acid in macrophage polarization: The significant role in inflammation and cancer. Int. Rev. Immunol. 2021, 1-15. [CrossRef] [PubMed]

205. Brown, T.P.; Bhattacharjee, P.; Ramachandran, S.; Sivaprakasam, S.; Ristic, B.; Sikder, M.O.F.; Ganapathy, V. The lactate receptor GPR81 promotes breast cancer growth via a paracrine mechanism involving antigen-presenting cells in the tumor microenvironment. Oncogene 2020, 39, 3292-3304. [CrossRef] [PubMed]

206. Raychaudhuri, D.; Bhattacharya, R.; Sinha, B.P.; Liu, C.S.C.; Ghosh, A.R.; Rahaman, O.; Bandopadhyay, P.; Sarif, J.; D’Rozario, R.; Paul, S.; et al. Lactate Induces Pro-tumor Reprogramming in Intratumoral Plasmacytoid Dendritic Cells. Front. Immunol. 2019, 10, 1878. [CrossRef]

207. Kleinfeld, A.M.; Okada, C. Free fatty acid release from human breast cancer tissue inhibits cytotoxic T-lymphocyte-mediated killing. J. Lipid Res. 2005, 46, 1983-1990. [CrossRef]

208. Pearce, E.L.; Walsh, M.C.; Cejas, P.J.; Harms, G.M.; Shen, H.; Wang, L.S.; Jones, R.G.; Choi, Y. Enhancing CD8 T-cell memory by modulating fatty acid metabolism. Nature 2009, 460, 103-107. [CrossRef]

209. Huang, S.C.; Everts, B.; Ivanova, Y.; O’Sullivan, D.; Nascimento, M.; Smith, A.M.; Beatty, W.; Love-Gregory, L.; Lam, W.Y.; O'Neill, C.M.; et al. Cell-intrinsic lysosomal lipolysis is essential for alternative activation of macrophages. Nat. Immunol. 2014, 15, 846-855. [CrossRef]

210. Pellegatti, P.; Raffaghello, L.; Bianchi, G.; Piccardi, F.; Pistoia, V.; Di Virgilio, F. Increased level of extracellular ATP at tumor sites: In vivo imaging with plasma membrane luciferase. PLoS ONE 2008, 3, e2599. [CrossRef]

211. Deaglio, S.; Dwyer, K.M.; Gao, W.; Friedman, D.; Usheva, A.; Erat, A.; Chen, J.F.; Enjyoji, K.; Linden, J.; Oukka, M.; et al. Adenosine generation catalyzed by CD39 and CD73 expressed on regulatory T cells mediates immune suppression. J. Exp. Med. 2007, 204, 1257-1265. [CrossRef] [PubMed]

212. Gourdin, N.; Bossennec, M.; Rodriguez, C.; Vigano, S.; Machon, C.; Jandus, C.; Bauche, D.; Faget, J.; Durand, I.; Chopin, N.; et al. Autocrine Adenosine Regulates Tumor Polyfunctional CD73(+)CD4(+) Effector T Cells Devoid of Immune Checkpoints. Cancer Res. 2018, 78, 3604-3618. [CrossRef]

213. Stagg, J.; Divisekera, U.; Duret, H.; Sparwasser, T.; Teng, M.W.; Darcy, P.K.; Smyth, M.J. CD73-deficient mice have increased antitumor immunity and are resistant to experimental metastasis. Cancer Res. 2011, 71, 2892-2900. [CrossRef] [PubMed]

214. Allard, B.; Longhi, M.S.; Robson, S.C.; Stagg, J. The ectonucleotidases CD39 and CD73: Novel checkpoint inhibitor targets. Immunol. Rev. 2017, 276, 121-144. [CrossRef]

215. Beavis, P.A.; Divisekera, U.; Paget, C.; Chow, M.T.; John, L.B.; Devaud, C.; Dwyer, K.; Stagg, J.; Smyth, M.J.; Darcy, P.K. Blockade of A2A receptors potently suppresses the metastasis of CD73+ tumors. Proc. Natl. Acad. Sci. USA 2013, 110, 14711-14716. [CrossRef] [PubMed]

216. Mittal, D.; Young, A.; Stannard, K.; Yong, M.; Teng, M.W.; Allard, B.; Stagg, J.; Smyth, M.J. Antimetastatic effects of blocking PD-1 and the adenosine A2A receptor. Cancer Res. 2014, 74, 3652-3658. [CrossRef]

217. Ohta, A. A Metabolic Immune Checkpoint: Adenosine in Tumor Microenvironment. Front. Immunol. 2016, 7, 109. [CrossRef]

218. Vaupel, P.; Hockel, M.; Mayer, A. Detection and characterization of tumor hypoxia using pO2 histography. Antioxid. Redox Signal. 2007, 9, 1221-1235. [CrossRef]

219. Terry, S.; Faouzi Zaarour, R.; Hassan Venkatesh, G.; Francis, A.; El-Sayed, W.; Buart, S.; Bravo, P.; Thiery, J.; Chouaib, S. Role of Hypoxic Stress in Regulating Tumor Immunogenicity, Resistance and Plasticity. Int. J. Mol. Sci. 2018, 19, 3044. [CrossRef]

220. Barsoum, I.B.; Hamilton, T.K.; Li, X.; Cotechini, T.; Miles, E.A.; Siemens, D.R.; Graham, C.H. Hypoxia induces escape from innate immunity in cancer cells via increased expression of ADAM10: Role of nitric oxide. Cancer Res. 2011, 71, 7433-7441. [CrossRef] 
221. Zhang, H.; Lu, H.; Xiang, L.; Bullen, J.W.; Zhang, C.; Samanta, D.; Gilkes, D.M.; He, J.; Semenza, G.L. HIF-1 regulates CD47 expression in breast cancer cells to promote evasion of phagocytosis and maintenance of cancer stem cells. Proc. Natl. Acad. Sci. USA 2015, 112, E6215-E6223. [CrossRef] [PubMed]

222. Samanta, D.; Park, Y.; Ni, X.; Li, H.; Zahnow, C.A.; Gabrielson, E.; Pan, F.; Semenza, G.L. Chemotherapy induces enrichment of CD47(+)/CD73(+)/PDL1(+) immune evasive triple-negative breast cancer cells. Proc. Natl. Acad. Sci. USA 2018, 115, E1239-E1248. [CrossRef] [PubMed]

223. Hatfield, S.M.; Kjaergaard, J.; Lukashev, D.; Belikoff, B.; Schreiber, T.H.; Sethumadhavan, S.; Abbott, R.; Philbrook, P.; Thayer, M.; Shujia, D.; et al. Systemic oxygenation weakens the hypoxia and hypoxia inducible factor 1alpha-dependent and extracellular adenosine-mediated tumor protection. J. Mol. Med. 2014, 92, 1283-1292. [CrossRef]

224. Corzo, C.A.; Condamine, T.; Lu, L.; Cotter, M.J.; Youn, J.I.; Cheng, P.; Cho, H.I.; Celis, E.; Quiceno, D.G.; Padhya, T.; et al. HIF-1alpha regulates function and differentiation of myeloid-derived suppressor cells in the tumor microenvironment. J. Exp. Med. 2010, 207, 2439-2453. [CrossRef] [PubMed]

225. Yan, M.; Jene, N.; Byrne, D.; Millar, E.K.; O’Toole, S.A.; McNeil, C.M.; Bates, G.J.; Harris, A.L.; Banham, A.H.; Sutherland, R.L.; et al. Recruitment of regulatory T cells is correlated with hypoxia-induced CXCR4 expression, and is associated with poor prognosis in basal-like breast cancers. Breast Cancer Res. 2011, 13, R47. [CrossRef]

226. Voloshin, T.; Fremder, E.; Shaked, Y. Small but mighty: Microparticles as mediators of tumor progression. Cancer Microenviron. 2014, 7, 11-21. [CrossRef]

227. Paolillo, M.; Comincini, S.; Schinelli, S. Fostering “Education”: Do Extracellular Vesicles Exploit Their Own Delivery Code? Cells 2021, 10, 1741. [CrossRef]

228. Giordano, C.; La Camera, G.; Gelsomino, L.; Barone, I.; Bonofiglio, D.; Ando, S.; Catalano, S. The Biology of Exosomes in Breast Cancer Progression: Dissemination, Immune Evasion and Metastatic Colonization. Cancers 2020, 12, 2179. [CrossRef]

229. Rong, L.; Li, R.; Li, S.; Luo, R. Immunosuppression of breast cancer cells mediated by transforming growth factor-beta in exosomes from cancer cells. Oncol. Lett. 2016, 11, 500-504. [CrossRef]

230. Xing, F.; Liu, Y.; Wu, S.Y.; Wu, K.; Sharma, S.; Mo, Y.Y.; Feng, J.; Sanders, S.; Jin, G.; Singh, R.; et al. Loss of XIST in Breast Cancer Activates MSN-c-Met and Reprograms Microglia via Exosomal miRNA to Promote Brain Metastasis. Cancer Res. 2018, 78, 4316-4330. [CrossRef]

231. Cereghetti, D.M.; Lee, P.P. Tumor-Derived Exosomes Contain microRNAs with Immunological Function: Implications for a Novel Immunosuppression Mechanism. Microrna 2014, 2, 194-204. [CrossRef]

232. Wen, S.W.; Sceneay, J.; Lima, L.G.; Wong, C.S.; Becker, M.; Krumeich, S.; Lobb, R.J.; Castillo, V.; Wong, K.N.; Ellis, S.; et al. The Biodistribution and Immune Suppressive Effects of Breast Cancer-Derived Exosomes. Cancer Res. 2016, 76, 6816-6827. [CrossRef] [PubMed]

233. Ngwa, W.; Irabor, O.C.; Schoenfeld, J.D.; Hesser, J.; Demaria, S.; Formenti, S.C. Using immunotherapy to boost the abscopal effect. Nat. Rev. Cancer 2018, 18, 313-322. [CrossRef] [PubMed]

234. Barcellos-Hoff, M.H. Integrative radiation carcinogenesis: Interactions between cell and tissue responses to DNA damage. Semin. Cancer Biol. 2005, 15, 138-148. [CrossRef] [PubMed]

235. Formenti, S.C.; Demaria, S. Systemic effects of local radiotherapy. Lancet Oncol. 2009, 10, 718-726. [CrossRef]

236. Wargo, J.A.; Reuben, A.; Cooper, Z.A.; Oh, K.S.; Sullivan, R.J. Immune Effects of Chemotherapy, Radiation, and Targeted Therapy and Opportunities for Combination With Immunotherapy. Semin. Oncol. 2015, 42, 601-616. [CrossRef]

237. Matsumura, S.; Wang, B.; Kawashima, N.; Braunstein, S.; Badura, M.; Cameron, T.O.; Babb, J.S.; Schneider, R.J.; Formenti, S.C.; Dustin, M.L.; et al. Radiation-induced CXCL16 release by breast cancer cells attracts effector T cells. J. Immunol. 2008, 181, 3099-3107. [CrossRef]

238. Timaner, M.; Bril, R.; Kaidar-Person, O.; Rachman-Tzemah, C.; Alishekevitz, D.; Kotsofruk, R.; Miller, V.; Nevelsky, A.; Daniel, S.; Raviv, Z.; et al. Dequalinium bl.locks macrophage-induced metastasis following local radiation. Oncotarget 2015, 6, 27537-27554. [CrossRef]

239. Ahn, G.O.; Brown, J.M. Matrix metalloproteinase-9 is required for tumor vasculogenesis but not for angiogenesis: Role of bone marrow-derived myelomonocytic cells. Cancer Cell 2008, 13, 193-205. [CrossRef]

240. Dovedi, S.J.; Adlard, A.L.; Lipowska-Bhalla, G.; McKenna, C.; Jones, S.; Cheadle, E.J.; Stratford, I.J.; Poon, E.; Morrow, M.; Stewart, R.; et al. Acquired resistance to fractionated radiotherapy can be overcome by concurrent PD-L1 blockade. Cancer Res. 2014, 74, 5458-5468. [CrossRef] [PubMed]

241. Deng, L.; Liang, H.; Burnette, B.; Beckett, M.; Darga, T.; Weichselbaum, R.R.; Fu, Y.X. Irradiation and anti-PD-L1 treatment synergistically promote antitumor immunity in mice. J. Clin. Investig. 2014, 124, 687-695. [CrossRef] [PubMed]

242. Chang, W.I.; Han, M.G.; Kang, M.H.; Park, J.M.; Kim, E.E.; Bae, J.; Ahn, S.; Kim, I.A. PI3Kalphadelta Inhibitor Combined With Radiation Enhances the Antitumor Immune Effect of Anti-PD1 in a Syngeneic Murine Triple-Negative Breast Cancer Model. Int. J. Radiat. Oncol. Biol. Phys. 2021, 110, 845-858. [CrossRef] [PubMed] 